\title{
Treatments for Hypertension in Type 2 Diabetes-Non-Pharmacological and Pharmacological Measurements
}

\author{
Kazuko Masuo ${ }^{1,2}$ and Gavin W. Lambert ${ }^{23}$ \\ ${ }^{1}$ Nucleus Network Ltd., \\ ${ }^{2}$ Human Neurotransmitters Laboratory Baker IDI Heart $\mathcal{E}$ Diabetes Institute, \\ ${ }^{3}$ Faculty of Medicine, Nursing and Health Sciences, Monash University, Melbourne
}

Australia

\section{Introduction}

Type 2 diabetes and hypertension are becoming a major worldwide health problem, besing associated with increasing prevalence of obesity and excess morbidity and mortality. Furthermore, hypertensive patients with diabetes or obesity are more predisposed to target organ damage, resulting stringent targets for blood pressure control [1-4]. Focusing on the close associations between obesity, hypertension and diabetes, the NHANES $[5,6]$ and the Behavioral Risk Factor Surveillance System (BRFSS) [7] studies showed very close relationships between the prevalence of obesity, hypertension, and diabetes (Figure 1). The Framingham Heart Study [8] demonstrated that diabetic subjects were at 2-fold higher risk mortality, comprising both cardiovascular and non-cardiovascular mortality. Evidence from these epidemiological studies indicates that obesity and weight gain are associated with an increased risk of hypertension [5-7, 9] and type 2 diabetes [7, 9, 10], and that intentional weight loss reduces the risk that currently overweight individuals will develop hypertension [11, 12] or type 2 diabetes [13] .

The clustering of cardiovascular risk factors associated with (abdominal) obesity is well established. Type 2 diabetes, itself, contributes strongly to mortality, morbidity, and cardiovascular risk, including myocardial infarction [14], cardiac events [15-18], stroke, atherosclerosis [19-21] and cardiovascular and renal complication [22, 23]. Hypertension is observed twice as frequently in diabetic patients than in the general population, and its prevalence is higher in type 2 diabetes than in type 1 diabetes. Diabetes accompanying cardiovascular diseases such as hypertension is associated with higher mortality and morbidity [24]. The World Health Organization Multinational Study of Vascular Disease in diabetes [17, 18] showed that even in the absence of proteinuria and hypertension, standardized mortality rates were significantly higher in patients with both type 1 and type 2 diabetes compared to those in the general population. Standardized mortality was higher in those with type 1 diabetes compared with type 2 diabetes. Both hypertension and proteinuria in diabetes were associated with a markedly high mortality risk by 11-fold for men with type 1 diabetes, and 5 fold for men with type 2 diabetes. A longer duration of diabetes and hypertension was a stronger predictor of mortality among diabetic and hypertensive patients. Therefore, those hypertensive patients with concomitant diabetes 
mellitus, or strong lifestyle or dietary factors to predict the development of type 2 diabetes such as obesity, should be treated as a matter of priority in order to prevent subsequent cardiovascular complications [25]. Importantly, the blood pressure goals of antihypertensive treatments is much lower in hypertensive patients with diabetes $(<130 / 80 \mathrm{mmHg})$ compared to hypertensive patients without complications [1, 4] (Table 1).
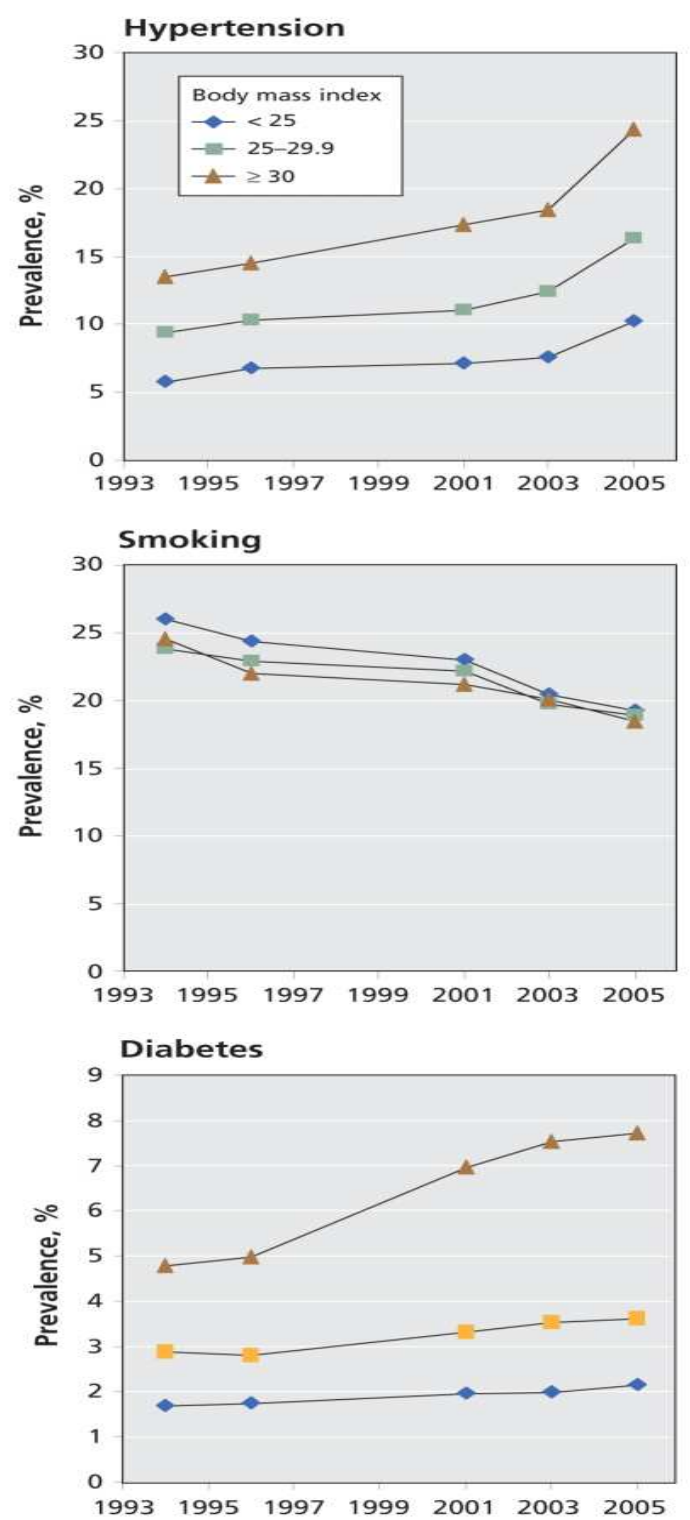

Fig. 1. Increased prevalence of diabetes and hypertension. [Reference 7] 


\begin{tabular}{|l|l|l|}
\hline & $\begin{array}{l}\text { Clinic blood } \\
\text { pressure }\end{array}$ & $\begin{array}{l}\text { Home blood } \\
\text { pressure }\end{array}$ \\
\hline Young/middle-aged persons & $<130 / 85 \mathrm{mmHg}$ & $<125 / 80 \mathrm{mmHg}$ \\
Elderly persons & $<140 / 90 \mathrm{mmHg}$ & $<135 / 85 \mathrm{mmHg}$ \\
$\begin{array}{l}\text { Diabetic patients with kidney disease } \\
\begin{array}{l}\text { Diabetic Patients after myocardial } \\
\text { infarction }\end{array}\end{array}$ & $<130 / 80 \mathrm{mmHg}$ \\
$\begin{array}{l}\text { Diabetic patients with cerebrovascular } \\
\text { disorders }\end{array}$ & $<130 / 80 \mathrm{mmHg}$ & $<125 / 75 \mathrm{mmHg}$ \\
\hline
\end{tabular}

Note: As the criteria for hypertension include a clinic blood pressure (BP) of 140/90 $\mathrm{mm} \mathrm{Hg}$ and a home $\mathrm{BP}$ of $135 / 85 \mathrm{~mm} \mathrm{Hg}$, the differences between clinic and home BP $(5 \mathrm{~mm} \mathrm{Hg})$ were simply applied to the clinic $\mathrm{BP}$ in each condition and derived provisional target home BP levels.BP, blood pressure. [Reference 2]

Table 1. Expected target blood pressure levels of antihypertensive treatment

The selection of the most suitable pharmacological treatments for those hypertensive patients with type 2 diabetes is governed to a degree by the knowledge of the physiological mechanisms underpinning the specifics of the conditions. Insulin resistance, stimulated renin-angiotensin-aldosterone system (RAAS), sympathetic nervous activation, and leptin resistance (hyperleptinemia) [26-29] are observed very frequently in type 2 diabetes, hypertension and obesity, and these factors appears to play an important role on the onset and developments of these conditions $[23,30,31)$.

The first line of treatments for obesity, type 2 diabetes, and hypertension are weight loss with a lifestyle modification such as low caloric diet and exercise [32-34], or, in those with more severe obesity or inability to undertake an exercise program, or bariatric surgery. Perhaps the most important and difficult aspect in controlling obesity is avoiding weight regain $[35,36]$. Anti-obesity drugs such as orlistat, sibtramine, rimonabant, and contrave [3740] have been developed, however these drugs were recently withdrawn from the markets in Europe, the United States and Australia due to serious side effects. Additionally, leptin administration (pegtlatyed recombinant leptin, PEG-OB; recombinant methionyl human leptin, r-metHu Leptin) has been investigated for effects of weight loss and their mechanisms, however, it has not yet been used clinically.

Despite the benefits of lifestyle modifications, additional pharmacological treatment for the management of hypertension is frequently needed. However, the choice of an antihypertensive drug is controversial for patients with associated with diabetes. Lind et al. [41] have previously summarized these metabolic effects with long-term antihypertensive treatments. Studies suggest that treatment with different antihypertensive drug classers may have varied effects on glucose and lipid metabolism [42]. In this context, it would be important to choose more beneficial antihypertensive drugs that have less adverse metabolic effects and to achieve stricter blood pressure goals for hypertension associated with type 2 diabetes and obesity.

An integrated cardiovascular risk management approach should be adopted. Aggressive blood pressure control is important, particularly in patients at high cardiovascular disease risk such as those with diabetes. Moreover, well-tolerated antihypertensive agents with protective benefits beyond blood pressure lowering, if this can be achieved, should be 
adopted [43]. Recently, many large scale clinical studies have shown that angiotensin II receptor blockers (ARBs) and angiotensin converting enzyme inhibitors (ACE inhibitors) are highly efficacious, well-tolerated antihypertensive agents [44, 45]. More disputed is whether there are additional benefits, beyond blood pressure lowering, leading to greater cardiovascular protection in obesity-related hypertension, metabolic syndrome, and diabetes. Recently, renin-inhibition with Aliskiren has been reported to impart an ameliorative effect on insulin resistance in type 2 diabetic mice [46]. Calcium channel blockers (CCBs), especially newer longer-acting dihydropyridines, may also provide favourable metabolic effects by improving insulin sensitivity and stimulated RAAS and sympathetic nervous activation in diabetes patients [47-49].

In this review, we discuss i) mechanisms of hypertension in type 2 diabetes; ii) the importance of weight loss as a non-pharmacological treatments for type 2 diabetes and hypertension; iii) achieving blood pressure reduction goals for hypertension with diabetes (JNC-7 and JSH 2009), and iv) pharmacological treatments for hypertension in type 2 diabetes.

2. Characteristics of hypertension in obesity and type 2 diabetes: insulin resistance, elevated sympathetic nervous activity, and stimulated the reninangiotensin-aldosterone system (RAAS) (Figure 2)

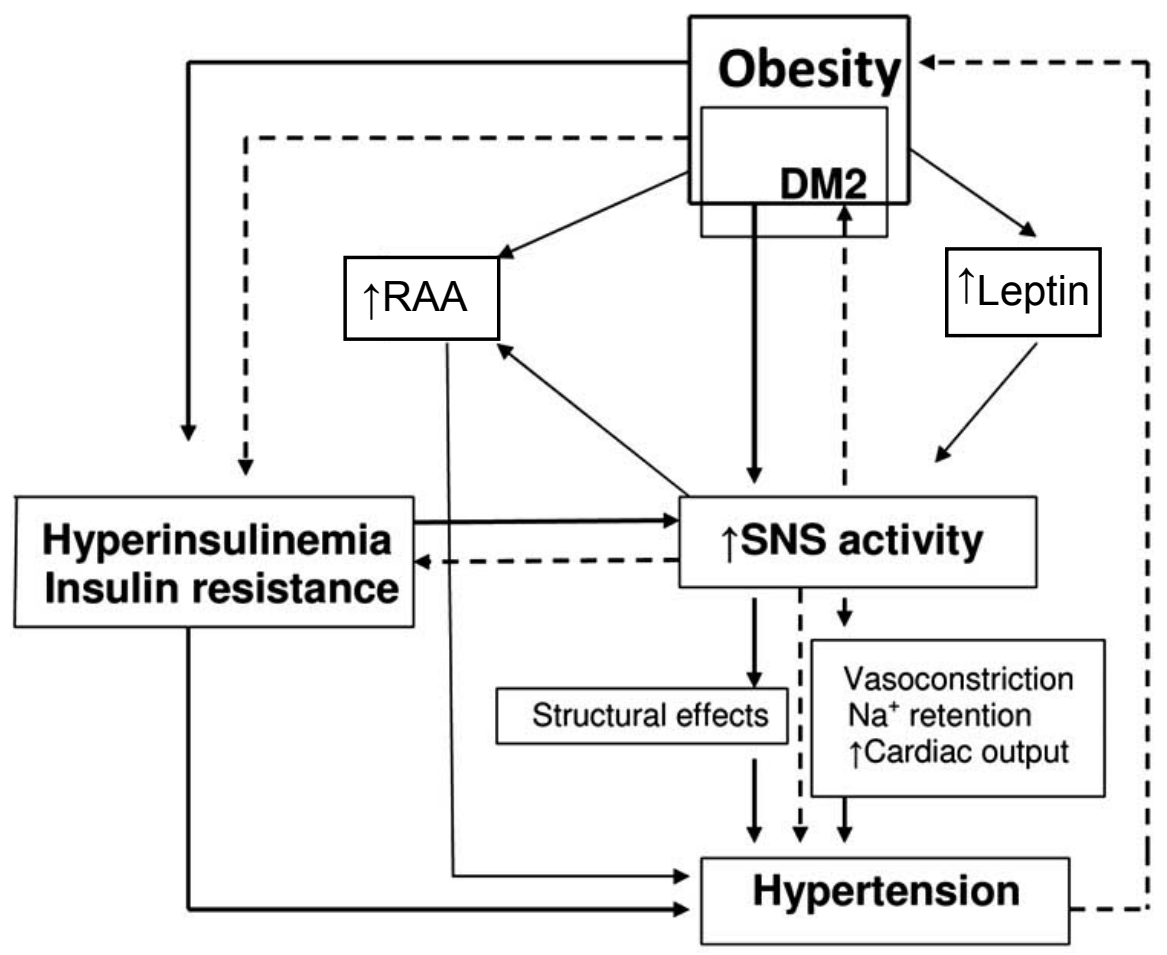

Fig. 2. Relationships between insulin resistance, sympathetic activation and stimulated reninangiotensin-aldosterone system (RAA) in type 2 diabetes and hypertension. [Reference 22] 
Data from many epidemiological and clinical studies has identified a close relationship between elevated sympathetic nervous system activity and insulin resistance / hyperinsulinemia in obesity (Figure 2) [22, 30, 50]. Several studies of longitudinal design have examined the effect of body weight changes (weight loss or weight gain) on sympathetic nervous system activity and insulin sensitivity (fasting plasma insulin levels and homeostatic model assessments of insulin resistance (HOMA-IR)). Elevations in sympathetic nervous activity and insulin levels during weight gain [51,52] and reductions of sympathetic nerve activity and insulin levels during weight loss [11, 33, 53] have been observed. These longitudinal studies have clearly shown that elevated sympathetic activity and insulin resistance are closely linked to obesity (weight gain), the onset of obesity and the maintenance of obesity. Similarly, sympathetic activation and insulin resistance are strongly linked to the onset and development of hypertension [51, 52] and diabetes [54]. Furthermore, stimulation of the renin-angiotensin-aldosterone system (RAAS) is frequently demonstrated in obesity and hypertension $[55,56]$, and may be related to insulin resistance either via direct or indirect mechanisms $[57,58]$.

\subsection{Insulin resistance}

Ferrannini et al. was the first investigator who reported insulin resistance or hyperinsulinemia in obese hypertensive patients $[59,60]$ as well as lean hypertensive subjects [61] over 20 years ago. They observed in obese subjects that the insulin response to oral glucose was twice as high in the hypertensive patients as in the normotensive subjects, yet the glucose incremental area was 3-fold higher in the former than in the latter, thus indicating more severe insulin resistance in obese hypertensive patients. In the hypertensive group, 2-hrs plasma insulin was strongly correlated with systolic BP levels [61]. In obese hypertensive patients, the occurrence of hypertension marks the presence of additional hyperinsulinemia and insulin resistance, independent of any impairment of glucose tolerance [60].

The EGIR-RISC study (The European group for the study of insulin resistance: relationship between insulin sensitivity and cardiovascular disease risk) studied insulin resistance and cardiovascular disease risk in 1500 healthy, middle-aged individuals over a 3-10 year period. Glucose tolerance and insulin sensitivity were measured with using an oral glucose tolerance test and the euglycemic insulin clamp. The EGIR-RISC Study demonstrated the importance of insulin resistance in the development of cardiovascular disease and diabetes, and has implications for the development of prevention and treatment strategies [62]. The EGIR-RISC study's documentation of strong relationships of blood pressure to both insulin action and circulating insulin levels is compatible with the distinct influences on BP by insulin resistance and compensatory hyperinsulinemia [63].

\subsection{Stimulated renin-angiotensin-aldosterone system}

Angiotension II (Ang II) produced in vessel walls disrupts the regulation of physiologically active substances by impairment of endothelium cell function [56]. Ang II mediated production of reactive oxygen species (ROS) promotes growth factors, cytokines and chemotactic factors relating to atherosclerosis [65]. A high level of insulin, as occurs in insulin resistance states, induces the activation of the tissue RAAS in blood vessels and the heart, and leads to an overproduction of Ang II in these tissues [33, 58]. High levels of insulin directly activate the expression and production of angiotensin, cell growth through 
the angiotensin I receptor and the conversion of Ang I to Ang II in vascular smooth muscle cells. Although the mechanisms leading to the initial activation of tissue Ang II in high-risk conditions such as type 2 diabetes and hypertension, RAAS blocking agents such as angiotensin converting enzyme inhibitors (ACE inhibitors) and Ang II receptor blockers (ARBs), inhibits the multi-factorial effects of Ang II and reduce the frequency of cardiovascular events as observed in the HOPE and LIFE studies [58, 66, 67]. The HOPE Study (the Heart Outcomes Prevention Evaluation study) showed that high plasma rennin activity is an independent predictor of major vascular events and mortality in a stable population of high-risk patients with atherosclerosis and/or diabetes [58]. The RAAS associated with insulin resistance and sympathetic nerve activation plays an important role of hypertension in type 2 diabetes.

\subsection{Sympathetic nervous activation}

Energy intake stimulates hyperinsulinemia and sympathetic nerve activity resulting in blood pressure elevation.. Insulin-mediated sympathetic nerve stimulation in obese subjects is a compensatory mechanism aimed at restoring the energy balance by increasing the metabolic rate [22,30]. Masuo et al. [51,52] have shown in a longitudinal study that heightened sympathetic nervous activity (as indicated by plasma norepinephrine levels) may be a prime mover for future weight gain and blood pressure elevations in originally nonobese, normotensive subjects, and that insulin resistance may be an ancillary factor. During weight loss studies, reductions in plasma norepinephrine followed by reductions in HOMA-IR were observed [33, 34, 53]. These observations show, at least, that the sympathetic nervous system activity associated with insulin resistances play a major role in the onset and development of hypertension with type 2 diabetes associated with obesity.

\section{Treatments for obesity}

\subsection{Lifestyle modification for weight loss}

Weight loss is recommended as the first-line treatment for obesity-induced hypertension and type 2 diabetes. The objective of treatment for obesity is both to reduce the high risk of cardiovascular events and to prevent the developments of hypertension and type 2 diabetes [68]. A limited number of epidemiological studies have shown that intentional weight loss and fat loss may reduce the all-cause mortality rate [69]. The US Diabetes Prevention Program [70]and the Oslo Diet and Exercise Study [71] have shown marked clinical benefits with lifestyle intervention, and modest weight loss, on the resolution of the metabolic syndrome and type 2 diabetes. Cohort studies with lifestyle modifications [72] and case control studies with bariatric surgeries [73, 74] provide some evidence that intentional weight loss has long-term benefits on all cause mortality in overweight adults. In a cohort of patients enrolled in a cardiac rehabilitation program, weight loss was associated with favourable long-term outcomes on the composite end-point of mortality and acute cardiovascular events (fatal and nonfatal myocardial infarction, fatal and nonfatal stroke, emergent revascularization for unstable angina pectoris, and congestive heart failure) [75]. Maintaining weight loss is often the greatest challenge, but, many clinical studies have demonstrated that weight loss associated with life-style modification adds to the efficacy of antihypertensive pharmacological treatment [11]. 
Ribeiro et al. [76], Trombetta et al. [77] and Tonacio et al. [78] compared the blood pressure lowering effects and forearm blood flow between a low caloric diet and exercise, and they observed that only exercise significantly increased forearm blood flow. Recently, Straznicky et al. [79] and Masuo et al.[80 have shown that a low caloric diet and exercise exert different effects on insulin resistance, the RAAS, and sympathetic nervous activity in obese hypertensive subjects, even though similar weight loss were observed.

\subsection{Bariatric surgery}

Gastric bypass and adjustable gastric banding are the two most commonly performed bariatric procedures for the treatment of morbid obesity or obesity which is resistant to lifestyle modification such as a low caloric diet plus exercise. Dixon et al. [74] showed that a gastric banding induced significant weight loss and resulted in better glucose control and less need for diabetes medication than conventional approaches to weight loss and diabetes control in a randomized controlled study in obese subjects with recently diagnosed type 2 diabetes. Nguyen et al. [81] and other investigators [82, 83] compared the effects on weight loss, mortality, morbidity and changes in quality of life in subjects with either gastric banding or gastric banding. The percent of excess weight loss at 4 years was higher in the gastric bypass group compared to the gastric banding group. Postoperative HOMA-IR correlated with \% weight loss [84]. Concurrent with restoration of insulin sensitivity and decreases in plasma leptin were dramatic decreases in skeletal muscle transcript levels of stearoyl coenzyme-A desaturase and pyruvate dehydrogenase kinase- 4 at 3 and 9 months after gastric banding and a significant decrease in peroxisome proliferation activated receptor-alpha-regulated genes at 9 months. Gumbs et al. [84] speculated that decrease in fat mass caused by bariatric surgery significantly affected circulating adipocytokines, which favourably impact on insulin resistance. Improvements in glucose metabolism and insulin resistance following bariatric surgery result in the short-term from decreased stimulation of the entero-insular axis by restricted calorie intake and in the long-term by decreased fat mass resulting changes in release of adipocytokines. Leptin levels drop and adiponectin levels rise following laparoscopic adjustable gastric banding, gastric bypass and biliopancreatic diversion. These changes correlate with weight loss and improvement in insulin sensitivity [84].

All forms of weight loss surgery (bariatric surgery) lead to calorie restriction, weight loss, decrease in fat mass, improvement in insulin resistance and type 2 diabetes mellitus [84]. Left ventricular relaxation impairment, assessed by tissue Doppler imaging, normalized 9 months after surgery [85]. Laparoscopic gastric bypass and gastric banding are both safe and effective approaches for the treatment of morbid obesity, but gastric bypass surgery seems to have better early weight loss and more rapid ameliorative effects on insulin resistance and adipocytokines, muscle metabolism and left ventricular function, however effects the long term effects with similar sustained weight loss are unknown.

\subsection{Pharmacological treatments for obesity (Orlistat, Sibtramine, and Rimonabant- Currently withdrawn in Europe, United States and Australia)}

Pharmacological treatment for the management of obesity is primarily aimed at weight loss, weight loss maintenance and risk reduction. Anti-obesity agents decrease appetite, reduce absorption of fat or increase energy expenditure. Recently, anti-obesity drugs such as orlistat, sibtramine and rimonabant have been developed placed on markets, however, the 
latter two were withdrawn from markets in Europe and in the United States due to serious adverse events including psychiatric and cardiovascular related concerns. Lorcaserin, taranabant, topiramate and bupropion with naltrexone are currently on phase III trials with demonstrated significant weight loss compared to placebo at more than 12 months. Some pharmacotherapies have also demonstrated clinical benefits without any side effects, however, further studies are required for a long-term safety [86]. Recently, contrave, a combination of two approved drugs of bupropio and naltrexone, completed Phase III trials with significant weight loss and was approved by FDA in 2010, but FDA declined to approve contrive due to serious cardiovascular adverse events in 2011 [86]. Importantly, obesity is, at least, in part, determined by genetic backgrounds [87], suggesting that a genetic approach to limiting obesity may find a place in the future.

\subsection{Leptin administration (pegylated recombinant leptin; PEG-OB, and recombinant methionyl human leptin; r-metHu Leptin)}

Lejeune et al. [88], Hukshorn et al. [89] and Westerterp-Plantenga, et al. [90] investigated the effect of weight loss and dietary restraint during and following weekly subcutaneous pegylated recombinant leptin (PEG-OB protein) administration in overweight men. Although treatment with PEG-OB protein led to a significantly greater body weight loss, energy expenditure, and dietary restraint, weight regain (rebound) was faster and stronger in subjects treated with PEG-OB compared to placebo. Asakawa et al. [91] administrated leptin intraperitoneally for 5 days in ob/ob mice. Intraperitoneal leptin administration caused significantly body weight loss of $13.2 \%$. Further, an additional ameliorative effect on anxiety was found with leptin administration. This finding, in ob/ob mice, appears not be relevant to the human condition. PEG-OB protein may theoretically work on human for weight loss, however, at this juncture there are few clinical studies available.

\section{Pharmacological treatments for the metabolic syndrome as a precursor of type 2 diabetes}

The metabolic syndrome, which may be considered to be the precursor of type 2 diabetes ,increases the risk of cardiovascular and renal events in hypertension. It has been associated with a wide range of classical and new cardiovascular risk factors as well as with early signs of subclinical cardiovascular and renal damage. The National Cholesterol Education Program's Adult Treatment Panel III definition uses easily measured clinical findings of increased abdominal circumference, elevated triglycerides, low high-density lipoproteincholesterol, elevated fasting blood glucose and/or elevated blood pressure. Three of these five are required for diagnosis. It should be noted that other definitions of metabolic syndrome focus more on insulin resistance and its key role in this syndrome [22] (Table 2).

Metformin has been shown to be helpful in subjects with metabolic syndrome or diabetes [92]. Atabek et al. [93] examined whether metformin treatment for 6 months was effective in reducing body weight and hyperinsulinemia, whilst also ameliorating insulin sensitivity indices in 120 obese adolescents with hyperinsulinemia. Before treatment, there were no significant differences between the metformin group and control group in terms of anthropometric data, metabolic parameters, and blood pressure levels. After metformin, there was a significant decline in body mass index, fasting insulin, $120 \mathrm{~min}$ insulin levels and HOMA-IR and a significant increase in the fasting glucose/insulin ratio. With regards 
to insulin sensitivity indices between the metformin treated and control groups, the metformin group displayed significantly improved metabolic control at the end of the study. These findings show the efficacy of metformin for obesity and insulin resistance (metabolic syndrome) in obese adolescents. While metformin has also been shown to prevent weight gain and improve blood glucose levels in hypertensive patients who received combination therapy of calcium antagonist (nitrendipine) and beta-blocker (atenolol) [94], in combination with drugs blocking the rennin-angiotensin system (ACEI or ARB), metformin may be associated with lactic acidosis and acute renal failure in patients with reduced renal function [95].

Whilst thiazolidinedione drugs (TZDs) may prove useful in the metabolic syndrome, or type 2 diabetes, a large concern has been expressed over the cardiovascular risks associated with rosiglitazone and pioglitazone [96]. Hsiao et al. [97] performed retrospective cohort study of 473,483 newly diagnosed patients with type 2 diabetes in order to evaluate the associations between oral antihyperglycemics (TZDs including rosiglitazone and pioglitazone, sulfonylureas, and metformin) with myocardial infarction, congestive heart failure, angina pectoris, stroke and transient ischemic attack. The findings extend the evidence provided further support to data derived from clinical trials that suggested that the disadvantages or harm caused by TZDs, especially rosiglitazone, may outweigh their benefits in patients with type 2 diabetes due to high risk for cardiac events. In addition, although the glycemic efficacy of TZDs are comparable to metformin, adverse effects and higher costs make TZDs less appealing for initial therapy. Among the TZDs, based on cardiovascular safety data, pioglitazone is the preferred choice. In combination with metformin, pioglitazone may be particularly beneficial for patients with metabolic syndrome and diabetes. In those patients who are achieving glycemic goals and tolerating the therapy without apparent complications, rosiglitazone may be continued [97]. Pioglitazone, but not metformin, in patients with type 2 diabetes significantly reduced hepatic lipid and increased adiponectin independent of weight change [98].

\section{Pharmacological treatments for hypertension (Figure 3)}

Although diabetes mellitus is associated with increased risks of death and cardiovascular events, in the Framingham Heart Study much of this excess risk wass attributable to coexistent hypertension [99]. Tight control of blood pressure (BP) significantly reduces cardiovascular morbidity and mortality in hypertensive patients with diabetes. In the United Kingdom Prospective Diabetes Study [100], a $10 \mathrm{mmHg}$ reduction in systolic blood pressure was superior to a $0.7 \%$ decrease in glycosylated haemoglobin A1c (HbA1c) with regards to reducing morbidity and mortality [101]. In the Hypertension Optimal Treatment Study $[102,103]$, the risk of cardiovascular events was decreased by $51 \%$ in those patients with type 2 diabetes randomized to the lower BP level. The HOT study demonstrated that monotherapy was successful in only $25-40 \%$ of patients, according to the target diastolic blood pressure in diabetic patients, and they wee needed at least 2 drugs, average 2.5-3 additional antihypertensive drugs to control blood pressure. [104, 105]. Based on these findings, contemporary treatment guidelines recommend a target blood pressure of $<130 / 80$ $\mathrm{mmHg}$ for patients with diabetes [106], however, evidence shows that most hypertensive patients with diabetes are very resistant to controlling hypertension and frequently require two or more types of antihypertensive medications in order to achieve blood pressure goals $[103,104,107,108]$. 


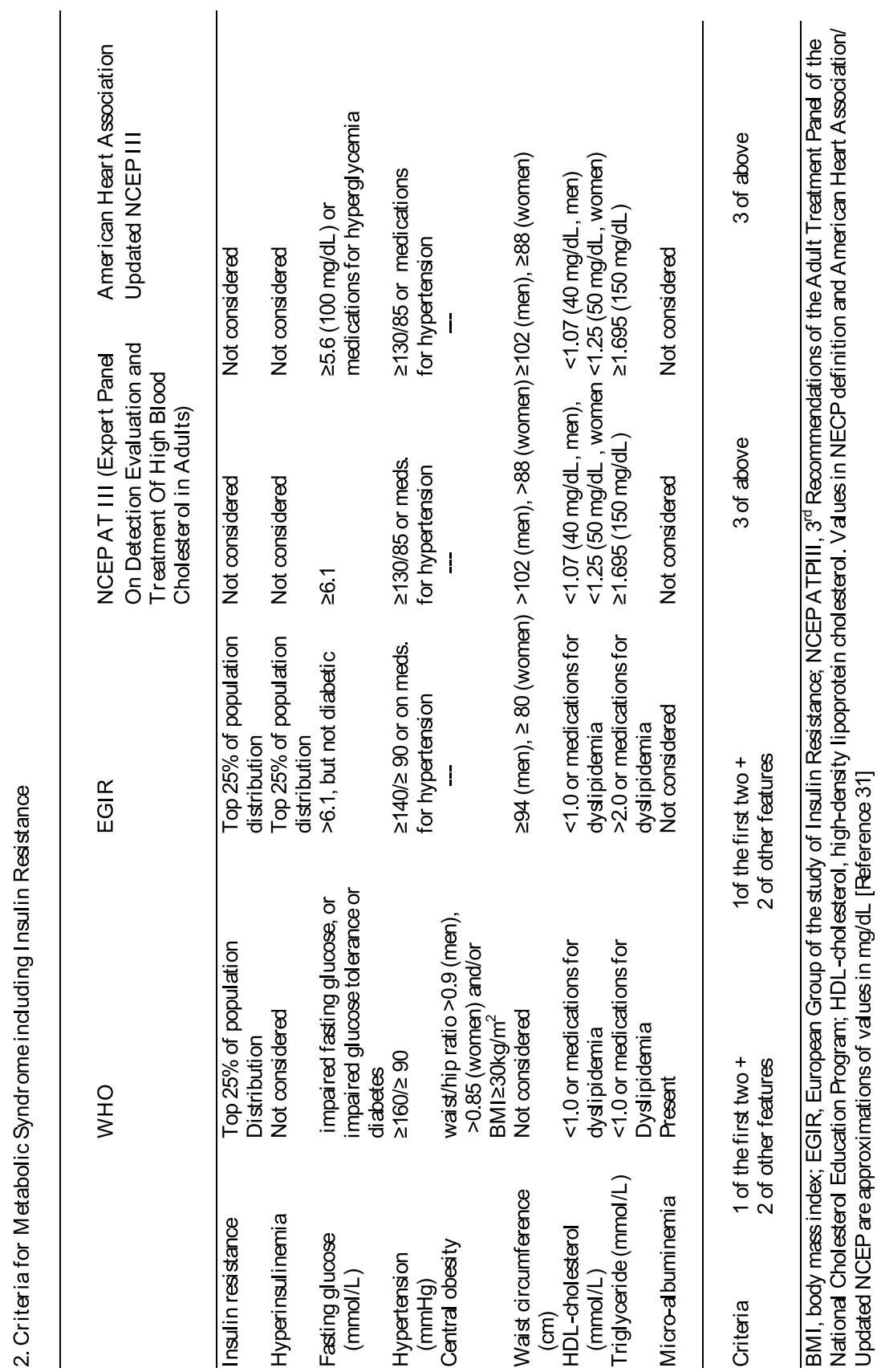

Fig. 3. The Guideline for Hypertension Treatments by the Seventh Report of the Joint National Committee on Prevention, Detection, Evaluation, and Treatment of High Blood Pressure (JNC-7) : Algorithm for Treatment of Hypertension [Reference 1] 
Class differences in the effects of antihypertensive medications on metabolic indices may therefore be an important consideration when choosing treatment for hypertensive patients with type 2 diabetes. Prospective, randomized studies with antihypertensive drugs have demonstrated differences between classes of drugs regarding effects on insulin resistance. Treatment with some beta-blockers or high-dose diuretics may be associated with impairment in insulin sensitivity,

- $\quad$ Principal Hypertension Treatment

1. Treat to $\mathrm{BP}<140 / 90 \mathrm{mmHg}$ or $\mathrm{BP}<130 / 80 \mathrm{mmHg}$ in patients with diabetes or chronic kidney disease

2. Majority of patients will require two medications to reach goal.

- $\quad$ Algorithm for Treatment of Hypertension

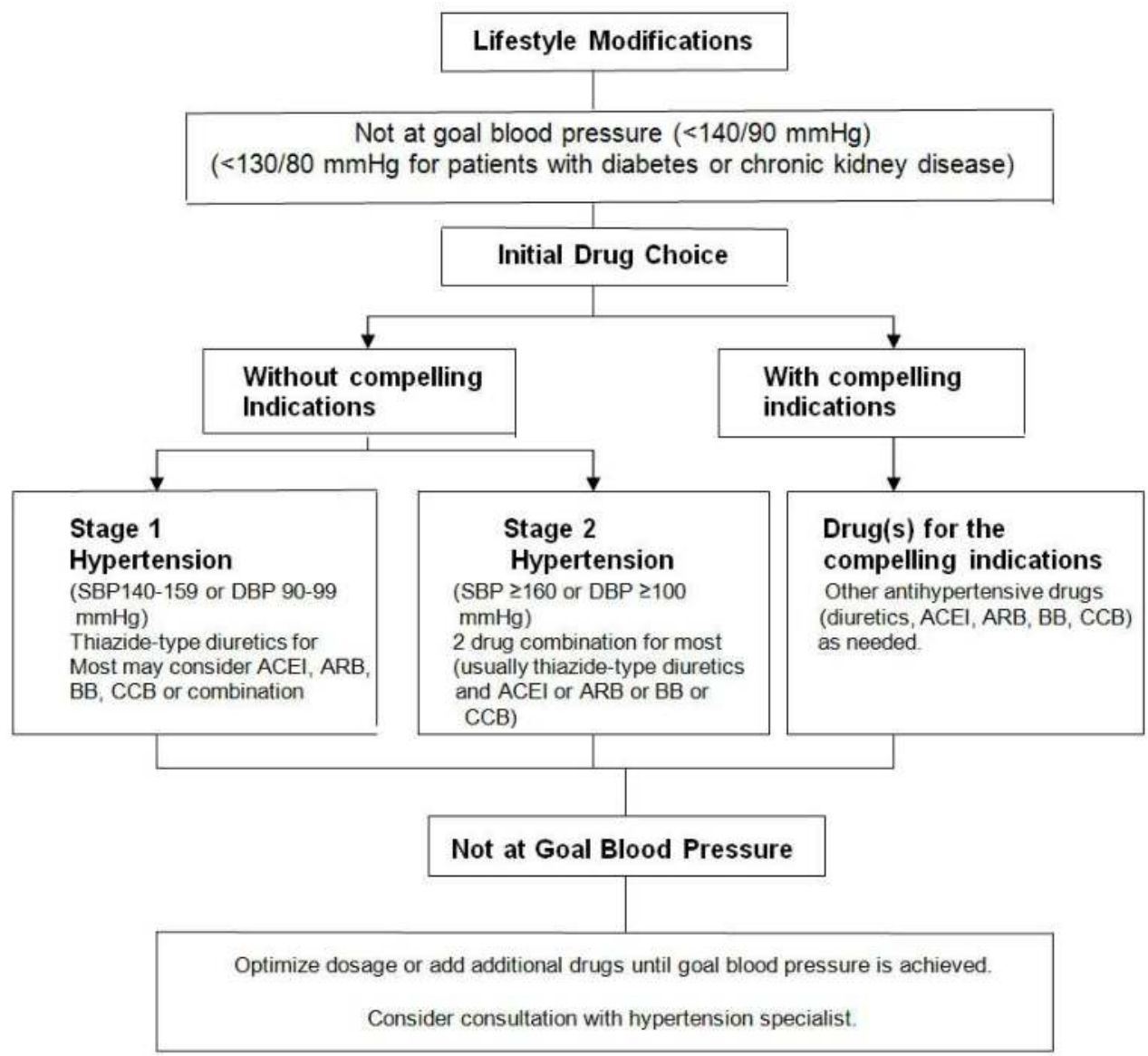

Fig. 3. The Guideline for Hypertension Treatments by the Seventh Report of the Joint National Committee on Prevention, Detection, Evaluation, and Treatment of High Blood Pressure (JNC-7) : Algorithm for Treatment of Hypertension [Reference 1] 
whereas angiotensin converting enzyme (ACE) inhibitors, angiotensin receptor blockers (ARBs), renin inhibitors, and calcium channel blockers (CCBs) are ameliorative or neutral. The most pronounced improvements have been obtained with alpha1-blockers. In a recent study, data indicated that moxonidine, an imidazoline1 receptor agonist, was effective in lowering blood pressure and improving insulin sensitivity in insulin-resistant patients. In populations at high risk of diabetes development, it may be justified to select drugs that improve insulin sensitivity when treating hypertension in insulin-resistant individuals [109]. The most important factor for choosing antihypertensive medications for hypertensive patients with diabetes is the prevention of the progression of renal damage [105, 110], which impacts drastically on mortality and morbidity in diabetic patients. Experience from clinical trials suggests that drugs that target the RAAS may have metabolic advantages over drugs such as beta-blockers and diuretics, but this conclusion has not been proved definitively. The number of antihypertensive medications needed for blood pressure control in patients with diabetes is largely dependent on the estimated glomerular filtration rate (renal function) rather than hyperglycemia control [110].

\subsection{Angiotensin-Converting Enzyme inhibitors (ACE inhibitors)}

The stimulation of the RAAS is a key factor in the development of hypertension in obesity. Pharmacological blockade of the RAAS not only improve blood pressure, but also has a beneficial effect on inflammation, oxidative stress, insulin sensitivity, glucose homeostasis, and resultant renal and cardio-protection. Several strategies are available for RAAS blockade, including angiotensin-converting enzyme inhibitors (ACE inhibitors), angiotensin II receptor blocker (ARBs), renin inhibitors (Aliskiren) and mineralocorticoidreceptor blockers, which have been proven in the clinical studies to result in improvements in cardiovascular disease and chronic kidney disease outcomes. Likewise, while hypertension in obesity, metabolic syndrome or type 2 diabetes, benefits from therapeutic lifestyle change, recently, clinical and epidemiological studies have shown that ACE inhibitors and ARBs are highly efficacious, persistent and well-tolerated antihypertensive agents, due to their cardio-and renal-protective benefits [58, 66, 67] . Moreover they have further beneficial effects in preventing complications of obesity and diabetes, such as progression of diabetic nephropathy, metabolic syndrome. Renin inhibitor may also exert favourable effects on insulin resistance [46]. In other words, the use of the RAAS blockers as initial treatment (both ARBs and ACEIs) in several cardiovascular, metabolic, obesity, and renal disorders (i.e. diabetes, ischemic heart disease, heart failure, and proteinuria) is now well-established.

The Heart Outcomes Prevention Evaluation (HOPE) study established that the significant effect of ACE inhibition (ramipril) on cardiovascular morbidity and mortality occurred through mechanisms beyond pure blood pressure control [58, 66]. Additionally, a recent analysis from the Blood Pressure Lowering Treatment Trialist's Collaboration showed that ARBs-based and ACE inhibitors -based treatment regimens were comparable in terms of the odds ratio for stroke and heart failure, independent of blood pressure reduction [111]. There is an emerging body of evidence suggesting that a combination approach to RAAS blockade with an ARB and an ACE inhibitor may further improve cardiovascular outcomes compared with mono-therapy with either agent alone [67]. In addition, some but not all clinical studies have shown that ACE inhibitors exert a favourable effect on insulin resistance [41, 49], lower plasma leptin, suppress the sympathetic nervous overactivity in obesity [11] and 
provide renal protection especially in diabetic patients with renal injury [43]. The sympathetic inhibition, however, is much less than that achieved with centrally acting imidazoline anti-hypertensive agents. Therefore, ACE inhibitors have s been recommended for use in special patients such as those with obesity, metabolic syndrome, diabetes, renal injury, or high risk of cardiovascular disease before the developments of ARBs [112]. The Irbesartan/HCTZ combination therapy and Blood Pressure Reductions in Diverse Patient Populations (INCLUSIVE) trial $[113,114]$ showed comparable antihypertensive efficacy and tolerability regardless of BMI or diabetes status.

\subsection{Angitension II receptor blockers (ARBs)}

The Ongoing Telmisartan Alone and in Combination with Ramipril Global Endpoint Trial (ONTARGET) program compared the efficacy of the angiotensin II receptor blocker (ARB) telmisartan, the angiotensin-converting enzyme (ACE) inhibitor ramipril, and combination therapy with telmisartan plus ramipril for reducing cardiovascular events $[115,116]$. The ONTARGET trial involved 25,588 high-risk cardiovascular or diabetic patients with organ damage and compared the effectiveness of telmisartan with that of ramipril and showed that the two drugs were 'therapeutically equivalent'. Telmisartan is now the only ARB with clinical trial evidence of cardiovascular protection equivalent to that of ramipril, which is widely regarded as the 'reference' drug for RAAS blockade in patients at increased cardiovascular risk [116, 117]. The ONTARGET program consists of 2 randomized, doubleblind, multicenter international trials: the principal trial, ONTARGET, and a parallel trial, Telmisartan Randomized Assessment Study in ACE-I Intolerant Patients with Cardiovascular Disease (TRANSCEND) [115]. Results of ONTARGET and the TRANSCEND have allowed us to better define the therapeutic approach in high-risk patients showing the favorable effects of either ramipril or telmisartan on blood pressure control and cardiovascular risk [115]. The results of the ONTARGET and TRANSEND studies in patients with high risk cardiovascular disease as well as a number of recent metaanalyses of randomized trials comparing the efficacy and safety of ACE inhibitors to ARBs and their combination in patients with heart failure, hypertension, and chronic kidney disease focused attention on the RAAS.

Emerging data from experimental studies indicates a variety of beneficial effects of telmisartan [118]. In addition to blocking the angiotensin II type 1 receptor, telmisartan activates the peroxisome proliferator-activated receptor (PPAR)-gamma, a well-known target for treatment of the metabolic syndrome and diabetes. Few studies have analysed intra-class differences in ARBs with respect to anti-diabetic or metabolic effects. Makita et al. [119] examined a prospective randomized study comparing a PPAR gamma-activating ARB (telmisartan) with a non-activating ARB (candesatrtan), to delineate the effects on metabolic factors associated with cardiovascular disease in 153 hypertensive patient with glucose intolerance. Telmisartan decreased body weight while increasing serum adiponectin levels in hypertensive patients with glucose intolerance. Candesartan did not achieve similar improvements in these patients. Among ARBs, telmisartan may have a greater impact on obesity-related diseases.

\subsection{Renin inhibitors}

Recent pharmaceutical developments have shown that direct inhibition ofrenin results in decreased angiotensin I and II production and decreased urinary aldosterone excretion. Like 
ACE inhibitors and ARBs, treatment with a direct renin inhibitor increases plasma renin concentration, but unlike the other RAAS inhibitors, treatment with a direct renin inhibitor decreases plasma renin activity. This unique combination of effects on the RAAS makes a direct renin inhibitor an attractive option to combine with other antihypertensive agents for the management of hypertension and its comorbidities [124]. Aliskiren/hydrochlorothiazide (HCTZ) therapy provides substantial BP reductions and may thus be a useful treatment option for older patients with stage 2 hypertension [125]. Clinical studies [126-128] including the ACTION study [125] have shown that combining aliskiren, with drugs representing each of the major classes of antihypertensive agents (thiazide diuretics, beta blockers, ACE inhibitors, ARBs, and CCBs) reduces blood pressure and improves markers of cardiovascular outcomes. Importantly, aliskiren had an ameliorative effect on insulin resistance in type 2 diabetic mice [46]. Persson et al. [129] investigated the effects of aliskiren on renal function and showed that aliskiren added to losartan reduced albuminuria and renal dysfunction and was well tolerated. In patients with type 2 diabetes, hypertension and albuminuria, aliskiren improved proteinuria [130]. Recently, Gao et al. [128] compared the efficacy between aliskiren and ARBs (losartan, valsartan and irbesartan) in 10 reports comprising 3,732 subjects and found that systolic and diastolic blood pressure reduction were similar. Results of several ongoing randomized clinical trials should provide additional insights into the potential of therapeutic combinations that include aliskiren to improve cardiovascular morbidity and mortality in patients with hypertension and related comorbidities. These studies have provided some further insight into the most effective strategy to prevent the adverse effects of RAAS activation. These insights may however need to be modified as the results of new strategies to block/inhibit the RAAS become available [131].

\subsection{Calcium Channel Blockers (CCBs)}

Calcium channel blockers (CCBs), especially newer long-acting dihydropyridines, may provide favourable metabolic effects by improving insulin sensitivity [49, 132, 133] and dampening the RAAS and sympathetic nervous activation in diabetes patients [47-49].

ACCOMPLISH (The Avoiding Cardiovascular events through COMbination therapy in Patients LIving with Systolic Hypertension) trial was designed in order to evaluate the indications for CCBs [108, 132-135]. The ACCOMPLISH study compare the cardiovascular outcomes between combination of ACE inhibitor (benazepril )/CCB (amlodipine) and ACE inhibitor (benazepril)/diuretic (hydrochlorothiazide, HCTZ) therapy in patients with hypertension and high risk of cardiovascular events. The primary end point of cardiovascular morbidity and mortality was reduced by $20 \%$ in the benazepril/CCB arm and was superior to benazepril/HCTZ during the 30 months-follow-up. For 2,842 diabetic patients at very high risk given previous cardiovascular or stroke events, benazepril/CCB had significantly lower prevalence of albuminuria or microalbuminuria compared to benazepri/HCTZ [108]. In the whole cohort, there were less coronary events including acute coronary events and revascularization in the group with the benazepril/CCB. Side effects were generally more frequent with $\mathrm{CCB}$ than with the HCTZ combinations. Furthermore, the ACCOMPLISH study also showed that benazepril/CCB demonstrated a marked ameliorative effect on serum creatinine and end-stage renal disease than benazepril/HCTZ [135]. Therefore, the ACCOMPLISH study provided evidence indicating that ACEI/CCB combinations are more effective in selected high-risk patients than are ACEI/HCTZ 
combinations [108, 132-135]. The AMANDHA Study [136] compared the effects on albuminuria between manidipine and amlodipine, as an additional medication on RAAS blockers. Both manidipine and amlodipine decreased blood pressure values to a similar extent. Urinary albumin excretion was reduced by $65.5 \%$ with manidipine versus $20 \%$ with amlodipine $(\mathrm{p}<0.01)$ at 6 months and 62.7 versus $16.6 \%(\mathrm{p}<0.01)$ at 18 months. Thus, the addition of manidipine, but not amlodipine, resulted in a large reduction in the urinary albumin excretion rate despite similar blood pressure reductions [136].

Wiener et al. [137] showed that a combined therapy with an ACE inhibitor (benazepril) and a CCB (amlodipine) over 12 weeks hadadditive benefits on large-vessel compliance at similar levels of blood pressure lowering, compared with monotherapy with an ACE inhibitor (enalapril) in hypertensive patients with type 2 diabetes $(52 \%$ vs. $32 \%, P<0.05)$ [137]. In addition, sub-studies to The International Nifedipine GITS study, Intervention as a Goal in Hypertension Treatment (INSIGHT), showed that nifedipine GITS was significantly more effective at preventing an increase in intima-media thickness in the carotid artery and significantly slowed the progression of coronary calcification, compared with diuretics, oamilozide, which are frequently observed in diabetes and atherosclerotic c patients [138]. The results from INSIGHT support incorporating nifedipine GITS in the management of high-risk hypertensive patients to prevent atherosclerosis-related illness and death [138]. These observations suggest CCBs has an ameliorative effects on atherosclerotic damage.

Interestingly, in the Valsartan Antihypertensive Long-Term Use Evaluation (VALUE) trial, the risk of new-onset diabetes was reported to be $23 \%$ lower among patients initiating therapy with valsartan versus amlodipine [139]. Unadjusted absolute risks of diabetes were 21.4 (95\% confidence interval (CI) 18.9-24.3) and 26.3 (95\% CI 24.3-28.3) per 1000 patientyears for valsartan and amlodipine, respectively; the corresponding relative risk (RR) for valsartan was 0.82 (95\% CI 0.70-0.94). The meta-analysis including 1.721 trials and 99,006 patients showed that CCBs were associated with a reduced incidence of new-onset type 2 diabetes (odds ratio 0.81; 95\% confidence interval [CI] 0.73-0.90; $p=0.0001$ ) compared with diuretic or beta-blocker therapy [140]. The reduction in new-onset type 2 diabetes was maintained when CCB were compared to only thiazide diuretics (OR 0.86; 95\% CI 0.75-0.99; $p=0.0346)$. Thus, CCBs may have benefits for treatments for hypertension in type 2 diabetes due to an ameliorative effect on insulin resistance and reductions in new-onset of type 2 diabetes.

\subsection{Imidazoline-receptor agonists (moxonidine)}

Class differences in the effects of antihypertensive agents on metabolic indices may therefore be an important consideration when choosing treatment for patients who exhibit these characteristics [109]. Moxonidine, which selectively targets imidazoline type-1 receptors in the sympathetic vasomotor centres of the rostral-ventrolateral medulla, is an effective antihypertensive and has been reported to exert favourable metabolic effects in preclinical and clinical studies [141]. In obese hypertensive rats, chronic, but not acute, moxonidine treatment partially restored insulin sensitivity [142]. Moxonidine reduced blood pressure associated with insulin sensitivity in obese hypertensive patients [143]. Moreover, although moxonidine and amlodipine were associated with comparable reductions in blood pressure, only moxonidine significantly decreased sympathetic nervous activity, improved insulin resistance and reduced plasma leptin levels [144]. A small dosage of moxonidine 
was effective to lowering blood pressure when it was used as a combination therapy with low-dose hydrochlorothiazides in hypertension with type 2 diabetes [145].

The MARRIAGE study (Moxonidine And Ramipril Regarding Insulin And Glucose Evaluation) has extended these preliminary observations by comparing the effects of moxonidine and the ACE inhibitor ramipril--and the combination of both drugs--on metabolic and haemodynamic parameters in patients with hypertension and impaired fasting glycaemia [146].

Both moxonidine and rilmenidine, were shown to exert beneficial effects, not only on blood pressure, but also lipid (reducing free fatty acids, triglycerides) [147, 148] and carbohydrate metabolism (improving glucose tolerance), and neurohormonal parameters such as plasma levels of norepinephrine, leptin, BNP, and ANP [149].

Moxonidine and rimenidine activates $\mathrm{I}_{1}$ receptors in the RVLM, reducing the activity of the sympathetic nervous system $[150,151]$. These $I_{1}$-agonists have been shown to produce pronounced and long-lasting BP reduction in different animal models of hypertension, including the spontaneously hypertensive rats $[152,153]$. Blood pressure reduction with moxonidine is usually accompanied by a reduction in heart rate which, however, is of shorter duration and lesser magnitude compared to the blood pressure reduction. Chronic administration of moxonidine to SHRs causes normalization of the heart and kidney damage (myocardial fibrosis, capillarization, regressive changes in myocytes, ventricular arrhythmia, left ventricular hypertrophy and renal glomerulosclerosis) in parallel with the reduction of blood pressure $[152,153]$. Direct injection of moxonidine into the vertebral artery of cats elicits a more pronounced fall in blood pressure compared with intravenous injection of an equivalent dose, indicating the centrally origins of the antihypertensive effects [153]. In addition, drugs of this class appear to have the capacity to favorably modify insulin sensitivity, which has particular relevance in the treatment of hypertensive diabetic patients and obese hypertensive patients who may be insulin resistant. In the hypertension accompanying maturity onset diabetes and obesity, with recent recommendations from advisory bodies setting lower BP goals, and with these lower targets often being reached only with combinations of antihypertensive agents, it is advisable that all drugs used in combination therapy exert a favorable, or at least a neutral effect on insulin resistance.

Sharma et al. [154] showed the efficacy of moxonidine in treating hypertension in those with metabolic syndrome or obesity. A post-marketing surveillance study (CAMUS) involving 772 obese hypertensive patients with hypertension with and without the metabolic syndrome was conducted in Germany. Approximately $50 \%$ of subjects had metabolic syndrome and patients were treated with moxonidine and followed for 8 weeks. Reductions in BP were similar between subjects with and without the metabolic syndrome (both from $168 / 97$ to $141 / 83 \mathrm{mmHg}$ ), but the BP reduction was particularly pronounced in patients with severe hypertension at baseline. The response rate (diastolic blood pressure $<$ or $=90$ $\mathrm{mmHg}$ or reduction $>$ or $=10 \mathrm{mmHg}$ ) of antihypertensive treatment with moxonidine was also similar ( $94.0 \%$ for all patients versus $93.8 \%$ for patients with metabolic syndrome). After 8 weeks of treatment, patients achieved a mean weight loss of $1.4 \mathrm{~kg}$, which was not surprisingly, particularly pronounced in obese patients. Moxonidine effectively reduced blood pressure in patients with the metabolic syndrome while simultaneously reducing body weight in obese patients.

In a study examining 77 obese hypertensive patients, Haenni et al. [155] used the hyperinsulinemia euglycemic glucose clamp technique and observed that treatment with 
moxonidine for 8-9 weeks significantly improved insulin sensitivity in insulin-resistant obese hypertensive patients, but not in insulin-sensitive obese hypertensive patients. Sanjuliani et al. [144] compared the responses of blood pressure, sympathetic nerve activity and plasma levels of insulin and leptin to moxonidine and amlopdipine treatment over a 24week period. Blood pressure reductions were of similar magnitude between both treatments. Moxonidine significantly reduced arterial plasma epinephrine and norepinephrine concentrations, orthostatic venous plasma norepinephrine and plasma insulin and leptin levels 120 minutes subsequent to an oral glucose loading, whereas amlodipine did not change any of those parameters. This study clearly demonstrated a comparable reduction in blood pressure with both antihypertensive drugs, but the neurohormonal and metabolic effects were different between the antihypertensive drugs.

\subsection{Low dose diuretics}

Low-dose of diuretics as a first agent in treatment of patients with hypertension and diabetes is well documented and widely recommended [156-160]. This treatment has beneficial effects on both morbidity and mortality while, previous general concern on the negative impact of diuretics on the different lipid parameters and metabolic effects appear not justified as, all long-term studies with low-dose diuretics have not been shown to affect lipid and glucose profiles in a negative way [161-163]. Moreover, in studies of a year or more duration, diuretics have been shown to reduce cardiovascular risk [145, 164-166]. Very recently, it was reported that Chlorthalidone reduced cardiovascular events more than Hydrochlorothiazide, suggesting that Chlorthalidone may be the preferred thiazide-type diuretics for hypertension in patients at a high risk of cardiovascular risk such as in diabetic or obese patients [167].

\subsection{Combination therapies}

The clinical combination of hypertension and diabetes carries a particular poor diagnosis. Achievement of target blood pressure $(<130 / 80 \mathrm{mmHg})$ in this patient category is crucial in decreasing premature morbidity and mortality. Thus, management of subjects with type 2 diabetes and associated hypertension needs to be early and aggressive, and must utilize a global approach. Now, especially for hypertensive patients with diabetes and obesity, multiple-medications are common [168].

\section{Conclusions}

Hypertension and type 2 diabetes are frequently associated with obesity. Life style modification with diet and exercise remains the initial treatment. Many subjects, however, fail to normalize/lose body weight, to maintain their weight loss, to control hyperglycemia, or to normalize blood pressure. Although diabetes mellitus is associated with increased risk of death and cardiovascular or renal events, much of this excess risk is attributable to coexistent hypertension.

Several large cohort trials have demonstrated that tight control of blood pressure significantly reduces cardiovascular morbidity and mortality and cardio-and renal complications in hypertensive patients with diabetes [101-103]. Based on these findings, contemporary treatment guidelines recommend a target systolic blood pressure/diastolic blood pressure of $<130 / 80 \mathrm{mmHg}$ for patients with diabetes, however, evidence shows that 
most hypertensive patients with diabetes are very resistant to controlling hypertension and frequently require two or more types of antihypertensive medications to achieve blood pressure goals [103, 110].

Class differences in the effects of antihypertensive medications on metabolic indices and renal protective effects may therefore be an important consideration when choosing treatment for patients who exhibit these characteristics. Hypertension in type 2 diabetes is characterized as insulin resistance, which is associated with cardiovascular morbidity and mortality, and cardiac- and renal complications. Another important factor for choosing antihypertensive medications for hypertensive patients with diabetes is the prevention of the progression of renal damage, which impacts the mortality and morbidity in diabetic patients. While antihypertensive agents such as beta-adrenoceptor antagonists may worsen insulin resistance and impair glucose tolerance, ACE inhibitors or ARBs exert positive metabolic effects and renoprotection. Experience from clinical trials suggests the renal protective drugs that target the RAAS and CCBs and beneficial.

This article provides a synthesis of current findings with non-pharmacological and pharmacological treatments for hypertension in type 2 diabetes. Treatment of hypertension in type 2 diabetes is important with regards to the prevention of cardiovascular complications. To this stage, the preferred antihypertensive drug classes are somewhat uncertain, and disputed, however, smaller dosage of each class of drugs might lead less side events. Currently a combination therapy with 2 or more different classes of antihypertensive drugs is recommended [1, 4, 168]. Use of ACEIs and ARBs as the initial treatment in hypertension in type 2 diabetes is usually advocated as these agents exert favourable effects on insulin sensitivity and provide renal protection. A strong case for wider use of CCBs and the imidazoline drugs (moxonidine, rilmenidine) can also be made

There are many aspects of the pathogenesis, prevention and treatment of type 2 diabetes that still need to be uncovered before a complete strategy to reduce the ongoing epidemic and burden of type 2 diabetes may be offered.

\section{References}

[1] Chobanian, A.V.; Bakris, G.L.; Black, H.R.; Cushman, W.C.; Green,. L.A.; Izzo, J.L. Jr.; Jones, D.W.; Materson, B.J.; Opari,l S.; Wright, J.T.; Roccella, E.J. Joint National Committee in Prevention, Detection, Ecaluation, and Treatment of High Blood Pressure. National Heart, Lung, and Blood Institute; National High Blood Pressure Education Program Coodinating Committee. Seventh Report of the Joint National Committee on Prevention, Detection, Evaluation, and Treatment of High Blood Pressure. Hypertension. 2003, 42(6), 1208-1252. www.nhlbi.nih.gov/guidelines/hypertension/; www.nhlbi.nih.gov/guidelines/hypertension/phycard.pdf;

[2] Whiteworth JA; World Health Organization, International Socity of Hypertension Writing Group. 2003 World Health Organization (WHO)/International Socity of Hypertension (ISH) statement on management of hypertension. J Hypertens. 2003; 21: 1983-1992.

[3] Olsen MH, Mallion JM, Rahn KM, Erdine S, Viigimae M, Laurent S, Agabiti-Rosei E, Mancia G, Schmieder RE, Cifkova R, Dominiczak A, Kjeldsen SE, Redon J, Zanchetti A, Nilsson P, Narkiewicz K: ESH Council. Agreement within Europe 
about antihypertensive treatment and education - results from the European Society of Hypertension questionnaire. J Hypertens. 2010; 28: 1593-1594.

[4] Ogihara, T.; Kikuchi, K.; Matsuoka, H.; Fujita, T.; Higaki, J.; Horiuchi, M, Imai, Y.; Imaizumi, T.; Ito, S.; Iwao, H.; Kario, K.; Kawano, Y.; Kim-Matsuyama, S.; Kimura, G.; Matsubara, H.; Matsuura, H.; Naruse, M.; Saito, I.; Shimada, K.; Shimamoto, K.; Suzuki, H.; Takishita, S.; Tanahashi, N.; Tsuchihashi, T.; Uchiyama, M.; Ueda, S.; Ueshima, H.; Umemura, S.; Ishimitsu, T.; Rakugi, H. Japanese Society of Hypertension Committee. The Japanese Society of Hypertension Guidelines for the Management of Hypertension (JSH 2009). Hypertens. Res. 2009, 32(1), 3-107.

[5] Phillips LK, Prins JB. The link between abdominal obesity and the metabolic syndrome. Curr Hypertens Rep. 2008; 10: 156-164.

[6] Ogden CL, Fryar CD, Carroll MD, Flegal KM. Advance Data from Vital and Health Statics. CDC. 2004; 347: 1-20.

[7] Mokdad AH, Ford ES, Bowman BA, Dietz WH, Vinicor F, Bales VS, Marks JS. Prevalence of obesity, diabetes, and obesity-related health risk factors, 2001. JAMA, 2003; 289: 76-79.

[8] Preis SR, Hwang SJ, Coady S, Pencina MJ, D'Agostino RB Sr, Savage PJ, Levy D, Fox CS. Trends in all-cause and cardiovascular disease mortality among women and men with and without diabetes mellitus in the Framingham Heart Study, 1950 to 2005. Circulation. 2009; 119: 1728-1735.

[9] Ford ES, Williamson DF, Liu S. Weight change and diabetes incidence: findings from a national cohort of US adults. Am J Epidemiolo. 1997; 146: 214-222.

[10] Resnick HE, Valsania P, Halter JB, Lin X. Relation of weight gain and weight loss on subsequent diabetes risk in overweight adults. J Epidemiol Communuty Health. 2000; 54: 596;602.

[11] Masuo K, Mikami H, Ogihara T, Tuck ML. Weight reduction and pharmacological treatment in obese hypertensives. Am J Hypertens. 2001; 14: 530-538.

[12] Straznicky NE, Lambert GW, McGrane MT, Masuo K, Dawood T, Nestle PJ, Eikelis N, Schlaich MP, Esler MD, Socratous F, Chopra R, Lambert EA. Weight loss may reserve blunted sympathetic neural responsiveness to glucose ingestion in obese subjectrs with metabolic syndrome. Diabetes. 2009; 58: 1126-11342.

[13] Will JC, Williamson DF, Ford ES, Calle EE, Thun MJ. Intentional weight loss and 13year diavetes incidence in overweight adults. Am J Public Healthy. 2002; 92: 12451248.

[14] Cho E, RimmEB, Stampfer MJ, Willett WC, Hu FB. The impact of diabetes mellitus and prior myocardial infarction on mortality from all causes and from coronary heart disease in men. J Am Coll Cardiol. 2002; 40: 954-960.

[15] Heidmann C, Boeing H, Pischon T, Nothlings U, Joost HG, Schulze MB. Association of a diabetes risk score with risk of myocardial infarction, stroke, specific types of cancer, and mortality: a prospective study in the European Prospective Investigation into Cancer and Nutrition (EPIC)-Potsdam cohort. Eur J Epidemiol. 2009; 24: 281-288.

[16] Young LH, Wackers FJ, Chyun DA, et al. for DIAD Investigators. Cardiac outcomes after screening for asymptomatic coronary artery disease in patients with type 2 diabetes: the DIAD study: a randomized controlled trial. JAMA. 2009; 301: 15471555 . 
[17] Wang SL, Head J, Steven L, Fuller JH. Excess mortality and its relation to hypertension and proteinuria in diabetic patients. The World health organization multinational study of vascular disease in diabetes. Diabetes Care. 1996; 19: 305-312.

[18] Morrish NJ, Wang SL, Stevens LK, Fuller JH, Keen H. Mortality and causes of death in the WHO multinational study of vascular disease in diabetes. Diabetologia. 2001; 44 Suppl 2: S14-S21.

[19] Iglseder B, Cip P, Malaimare L, Ladurner G, Paulweber B. The metabolic syndrome is a stronger risk factor for early carotid atherosclerosis in women than in men. Stroke. 2005; 36: 1212-1217.

[20] Kawamoto R, Tomita H, Ohtsuka N, Inoue A, Kamitani A. Metabolic syndrome, diabetes and subclinical atherosclerosis as assessed by carotid intima-media thickness. J Atheroscler Thromb. 2007; 14: 78-85.

[21] Bertoni A, Wong ND, Shea S, et al. Insulin resistance, metabolic syndrome, and subclinical atherosclerosis. The Multi-Ethnic Study of Atheroclerosis (MESA). Diabetes Care. 2007; 30: 2951-2956.

[22] Masuo K, Rakugi H, Ogihara T, Esler MD, Lambert GW. Cardiovascular and renal complications of type 2 diabetes in obesity: role of sympathetic nerve activity and insulin resistance. Curr Diab Rev. 2010; 6: 58-67.

[23] Straznicky NE, Grima MT, Lambert EA, Eikelis N, Dawood T, Lambert GW, Nestel PJ, Masuo K, Sari CI, Chopra R, Mariani JA, Schlaich MP. J Hypertens. Exercise augments weight loss induced improvement in renal function in obese metabolic syndrome individuals. 2011; 29: 553-564.

[24] Held C, Gerstein HC, Yusuf S, et al. for the ONTARGET/TRANSCEND investigators. Glucose levels predict hospitalization for congestive heart failure in patients at high cardiovascular risk. Circulation. 2007; 115: 1371-1375.

[25] Schulze MB, Hoffmann $\mathrm{K}$, Boeing $\mathrm{H}$, et al. An accurate risk score based on anthropometric, dietary, and lifestyle factors to predict the development of type 2 diabetes. Diabetes Care. 2007; 30: 510-515.

[26] Bandaru P, Shankar A. Association between plasma leptin levels and diabetes mellitus. Metab Syndr Relat Disord. 2011; 9: 19-23.

[27] Shankar A, Xiao J. Positive relationship beterrn plasma leptin level and hypertension. Hypertension. 2011; 56: 623-628.

[28] Sari R, Balci MK, Apaydin C. The relationship between plasma leptin levels and chronic complication in patients with type 2 diabetes mellitus. Metab Syndr Relat Disord. 2010; 8: 499-503.

[29] Masuo K, Katsuya T, Ogihara T, Tuck ML. Acute hyperinsulinemia reduces plasma leptin levels in insulin-sensitive Japanese men. Am J Hypertens. 2005; 18: 235-243.

[30] Esler M, Straznicky N, Eikelis N, Masuo K, Lambert G, Lambert E. Mechanisms of sympathetic activation in obesity-related hypertension. Hypertension. 2006; 48: 787796.

[31] Masuo K, Esler MD. Role of sympathetic nerve activity in obesity, hypertension, and metabolic syndrome. Curr Hypertens Rev. 2010; 6: 83-91.

[32] Straznicky NE, Lambert EA, Lambert Gw, Masuo K, Esler MD, Nestel PJ. Effects of dietary weight loss on sympathetic activity and cardiac risk factors associated with the metabolic syndrome. J Clin Endocrinol Metab. 2006; 90: 5998-6005 
[33] Weir MR, Dzau VJ. The renin-angiotensin-aldosterone system: a specific target for hypertension management. Am J Hypertens. 1999; 12 (Pt 3):205S-213S.

[34] Masuo K, Mikami H, Ogihara T, Tuck ML. Different mechanisms between weight losssensitove and -resistant blood pressure reduction in obese subjects. Hypertens Res. 2001; 24: 371-374.

[35] Ross R. The challenge of obesity treatment: avoiding weight regain. CMAJ. 2009; 180: 997-998.

[36] Masuo K, Katsuya T, Kawaguchi H, Fu Y, Rakugi H, Ogihara T, Tuck ML. Rebound weight gain as associated with high plasma norepinephrine levels that are mediated through polymorphism in beta 2-adrenoceptor. Am J Hypertens. 2005; 18: 1508-1516.

[37] Whiltlock EA, O'Connor EP, Williams SB, Beil TL, Lutz KW. Evid Rep Technol Assess (Full Rep). 2008; 170: 1-308.

[38] Willemen MJ, Mantel-Teeuwisse AK, M Straus SM, Leufkens HG, Egberts AC, M Sturkenboom MC. Pharmacolepidemiol Drug Safe. 2009; May 5. [Epub ahead of print].

[39] Siebenhofer A, Horvath K, Jeitler K, Berghold A, Stich AK, Matyas E, Pignitter N, Siering U. Long-term effects of weight-reducing drugs in hypertensive patients. Cochrane Database Syst Rev. 2009; 8: CD007654.

[40] Czernichow S, Lee CM, Barzi F, Greenfield JR, Baur LA, Chalmers J, Woodward M, Huxley RR. Efficacy of weight loss drugs on obesity and cardiovascular risk factors in obese adolescents: a meta-analysis of randomized controlled trials. Obes Rev. 2009; Jun 1 [Epub a head of print].

[41] Lind L, Pollare T, Berne C, Lithell H. Long-term metabolic effects of antihypertensive drugs. Am Heart J. 1994; 128: 1177-1183.

[42] Padwal R, Laupacis A. Antihypertensive therapy and incidence of type 2 diabetes: a systemic review. Diabetes Care. 2004; 27: 247-255.

[43] Shammas NW, Sica DA, Toth PP. A guide to the management of blood pressure in the diabetic hypertensive patients. Am J Cardiovasc Drugs. 2009; 9: 149-162.

[44] Verma S, Gupta M, Holmes DT, Xu L, Tech H, Gupta S, Yusuf S, Lonn EM. Plasma renin activity predicts cardiovascular mortality in the Heart Outcomes Prevention Evaluation (HOPE) study. Eur Heart J. 2011. March 17. [Epub ahead of print].

[45] Nosadini R, Tonolo G. Cardiovascular and renal protection in type 2 diabetes mellitus: the role of calcium channel blockers. J Am Soc Nephrol. 2002; 13 Suppl 3: S216S223.

[46] Iwai M, Kanno H, Tomono Y, Inaba S, Senmba I, Furuno M, Mogi M, Horiuchi M. Direct renin inhibition improved insulin resistance and adipose tissue dysfunction in type 2 diabetic KK-A9y) mice. J Hypertens. 2010; 28: 1471-1481.

[47] Masuda T, Ogura MN, Moriya T, Takahira N, mMatsumoto T, Kuysuna T, Hara M, Aibe N, Noda C, Izumi T. Beneficial effects of L- and N-type calcium channel blocker on glucose and lipids metabolism and renal function in patients with hypertension and type II diabetes mellitus. Cardiovasc Ther. 2011; 29: 46-53.

[48] Toba H, Yoshida M, Yojo C, Nakano A, Oshima Y, Kojima Y, Noda K, Kobara M, Nakata T. L/N-type calcium channel blocker cilinidipine ameliorates proteinuria and inhibits the renal renin-angiotensin-aldosterone system in deoxycorticosterone acetate-salt hypertensive rats. Hypertens Res. 2011; Jan 27. [Epub ahead of print]. 
[49] Masuo K, Mikami H, Ogihara T, Tuck ML. Metabolic effects of long-term treatments with nifedipine-retard and captopril in young hypertensive patients. Am J Hypertens. 1997; 10: 600-610.

[50] Masuo K. Obesity-related hypertension: role of the sympathetic nervous system, insulin, and leptin. Curr Hypertens Rep. 2002; 4: 112-118.

[51] Masuo K, Mikami H, Ogihara T, Tuck ML. Weight gain-induced blood pressure elevation. Hypertension. 2000; 35: 1135-1140.

[52] Masuo K, Katsuya T, Fu Y, Rakugi H, Ogihara T, Tuck ML. Beta2- and beta3adrenoceptor polymorphisms are related to the onset of weight gain and blood pressure elevation over 5 years. Circulation. 2005; 111; 3429-3434.

[53] Masuo K, Kstsuya T, Kawaguchi H, Fu Y, Rakugi H, Ogihara T. Rebound weight gain as associated with high plasma norepinephrine levels that are mediated through polymorphisms in the beta2-adrenoceptor. Am J Hypertens. 2005; 18: 1508-1516.

[54] Huggett RJ, Scott EM, Gilbey SG, Stoker JB, Mackintosh AF, Mary DA. Impact of type 2 diabetes mellitus on sympathetic neural mechanisms in hypertension. Circulation. 2003; 108: 3097-3101.

[55] Stump CS, Henriksen EJ, Wei Y, Sowers JR. The metabolic syndrome: role of skeletal muscle metabolism. Ann Med. 2006; 38: 389-402.

[56] Kamide K, Rakugi H, Ogihara T. Insulin resistance and the renin-angiotensinaldosterone system in metabolic syndrome and obesity-related hypertension. Curr Hypertens Rev. 2010; 6: 100-103.

[57] Matayoshi T, Kamide K, Takiuchi S, Horio T, Yoshihara F, Nakamura S, Nakahara H, Kawano Y. Relationship between insulin resistance and the renin-angiotensin system: analysis for patients with essential and renovascular hypertension. Clin Exp Hypertens. 2007; 29: 479-487.

[58] Kamide K, Rakugi H, Ogihara T, Nagai M, Takiuchi S, Matsukawa N, Higaki J, Kawano Y, Ogihara T, Tuck ML. Insulin-mediated modulation of the endothelial reninangiotensin system and vascular cell growth. J Hypertens. 2004; 22: 121-127.

[59] Ferrannini E. Physiological and metabolic consequence of obesity. Metabolism. 1995; 44 (Suppl 3): 15-17.

[60] Manicardi V, Camellini L, Bellodi G, Coscelli C, Ferrannini E. Evidence for an association of high blood pressure and hyperinsulinemia in obese man. J Clin Endocrinol Metab. 1988; 62: 1302-1304.

[61] Ferrannini E, Buzzigoli G, Bonadonna R, Giorico MA, Oleggini M, Graziadei L, Pedrinelli R, Brandi L, Bevilacqua S. Insulin resistance in essential hypertension. $N$ Engl J Med. 1987; 317: 350-357.

[62] Hills SA, Balkau B, Coppack SW, Dekker JM, Mari A, Natali A, Walker M, Ferrannini E; EGIR-RISC Study Group. The EGIR-RISC Study (The European Group for the study of insulin resistance: relationship between insulin sensitivity and cardiovascular disease risk): I. Methodology and objectives. Diabetologia 2004; 47: 566-570.

[63] Ferrannini E, Natali A, Capaldo B, Lehtovirta M, Jacob S, Yki-Jarvinen H. Insulin resistance, hypertensulinemia, and blood pressure: role of age and obesity. European Group for the Study of Insulin Resistance (EGIR). Hypertension. 1997; 30: 1144-1149. 
[64] Ferranninini E. Analysis of data on insulin resistance from the European group for the study of insulin resistance: focus on obesity and hypertension. Endocr Pract. 2003; 9 suppl 2: 43-49.

[65] Harrison DG, Gongora MC. Oxidative stress and hypertension. Med Clin North Am. 2009; 93: 621-635.

[66] Van Mieghem W. Prevention of major cardiovascular events with an angiotensinconverting enzyme inhibitor or an angiotensin receptor blocker early or late after stroke. J Hypertens Suppl. 2009; 27: S26-S31.

[67] Slight P, Jakobsen A, Heroys J, Ralph A, Ress T, Shaw M. No HOPE without proof: do ARBs meet the standard for cardiovascular protection? Medscape J Med. 2008; 10 Suppl: S6.

[68] Redon J, Cifkova R, Laaurent Sm, Nilsson P, Narkiewicz K, Erdine S, Mancia G; Scientific Council of the European Society of Hypertension. J Hypertens. 2008; 26: 1891-1900.

[69] Allison DB, Zannolli R, Faith MS, Heo M, Pietrobelli A, VanItallie TB, Pi-Sunyer FX, Heymsfield SB. Weight loss increases and fat loss decreases all-cause mortality rate: results from two independent cohort studies. Int J obes Relat Metab Disord. 1999; 23: 603-611.

[70] Orchard TJ, Temprosa M, Goldberg R, Haffner S, Ratner R, Marcovina S, Fowler S. The effect of metformin and intensive lifestyle intervention on the metabolic syndrome: The Diabetes Prevention Program randomized trial. Am Intern Med. 2005; 142: 611619.

[71] Anderssen SA, Carroll S, Urdal P, Holme I. Combined diet and exercise intervention reverses the metabolic syndrome in middle-aged males: results from the Oslo Diet and Exercise Study. Scand J Med Sci Sports. 2007; 17: 687-695.

[72] Poobalan AS, Aucott LS, Smith WCS, Avenell A, Jung R, Broom J. Long-term weight loss effects on all cause mortality in overweight/obese populations. Obes Rev. 2007; 8: 503-513.

[73] Sjostrom L, Narbro K, Sjostrom CD< et al. Effects of bariatric surgery on mortality in Swedish obese subjects. N Engl J Med. 2007; 357: 741-752.

[74] Dixon JB, O’Brien PE, Playfair J, Chapman L, Schachter LM, Skinner S, Proietto J, Bailey M, Anderson M. Adjustable gastric banding and conventional therapy for type 2 diabetes: a randomized controlled trial. JAMA. 2008; 299: 316-323.

[75] Sierra-Johnson J, Romeo-Corral A, Somers VK, Lopez-Jimenez F, Thomas RJ, Squires RW, Allison TG. Prognostic importance of weight loss in patients with coronary heart disease regardless of initial body mass index. Eur J Cardiovasc Prev Rehabil. 2008; 15: 336-340.

[76] Ribeiro MM, Silva AG, Santos NS, Guazzelle I, Matos LN, Trombetta IC, Halpern A, Negrao CE, Villares SM. Diet and exercise training restore blood pressure and vasodilatory responses during physiological maneuvers in obese children. Circulation. 2005; 111; 1915-1923.

[77] Trombetta IC, Batalha LT, Rondon MU, Laterza MC, Kuniyoshi FH, Gowdak MM, Barretto AC, Halpern A, Villares SM, Negrao CE. Weight loss improves neurovascular and muscle metaboreflex control in obesity. Am J Physiol Heart Circ Physiol. 2003; 11: H974-H982. 
[78] Tonacio AC, Trombetta IC, Rondon MU, Batalha LT, Kuniyoshi FH, Laterza MC, Suzuki PH, Gowdak MM, Barretto AC, Halpern A, Villares SM, Negrao CE. Effects of diety and exercise training on neurovascular control during mental stress in obese women. Braz J Med Biol Res. 2006; 39: 53-62.

[79] Straznicky N, Grima MT, Eikelis N, Nestel PJ, Dawood T, Schlaich MP, Chopra R, Masuo K, Esler MD, Sari CI, Lambert GW, Lambert EA. The effects of weight loss versus weight loss maintenance on sympathetic nervous system activity and metabolic syndrome components. JCEM 2011; 96: 6503-8

[80] Masuo K, Rakugi H, Ogihara T, Lambert GW. Different mechanisms in weight lossinduced blood pressure reduction between a calorie restricted diet and exercise. Hypertens Res. 2011 (in press).

[81] Nguyen NT, slone JA, Nguyen XM, Hartman JS, Hoyt DB. A prospective randomized trial of laparoscopic gastric bypass versus laparoscopic adjustable gastric banding for the treatment of morbid obesity: outcomes, quality of life and costs. Ann Surg. 2009; Aug 27 [Epub ahead of print]

[82] Ballantyne GH, Wasielewski A, Saunders JK. The surgical treatment of type II diabetes mellitus: Changes in HOMA insulin resistance in the first year following laparoscopic Rou-en-Y gastric bypass (LRYGB) and laparoscopic adjustable gastric banding (LAGB). Obes Surg. 2009; 19: 1297-1303.

[83] Trakhenbroit MA, Leichman JG, Algahim MF, Miller CC $3^{\text {rd }}$, Moody FG, Lux TR, Taegtmeyer $\mathrm{H}$. Body weight, insulin resistance, and serum adipokine levels 2 years after 2 types of bariatric surgery. Am J Med. 2009; 122: 435-442.

[84] Gumbs AA, Modlin IM, Ballantyne GH. Changes in insulin resistance following bariatric surgery: role of caloric restriction and weight loss. Obes Surg. 2005; 15: 462-73.

[85] Leichman JG, Wilson EB, Scarborough T, Aguilar D, Miller CC 3rd, Yu S, Algahim MF, Reyes M, Moody FG, Taegtmeyer H. Dramatic reversal of derangements in muscle metabolism and left ventricular function after bariatric surgery. Am J Med. 2008; 121: 966-973.

[86] Ioannides-Demos LI, Piccenna L, McNeil JJ. Pharmacotherapies for obesity: Past, currect, and future therapies. J Obes. 2011, Article ID 179674. Doi: $10.1155 / 2011 / 79674$.

[87] Masuo K, Lambert GW. Relations of adrenoceptor polymorphisms with obesity. J Obes. 2011. Article ID 609485. Doi:10.1155/2011/609485

[88] Lejeune MP, Hukshorn CJ, Saris WH, Westerterp-Plantenga MS. Effect of dietary restraint during and following pegylated recombinant leptin (PEG-OB) treatment of overweight men. Int J Obes Relat Metab Disord. 2003; 27: 1494-1499.

[89] Hukshorn CJ, Westerterp-Plantenga MS, Saris WMH. Pegylated human recombinant leptin (PEG-OB) causes additional weight loss in severely energy-restricted, overweight men. Am J Clin Nutr. 2003; 77: 771-776.

[90] Westerterp-Plantenga MS, Saris WH, Hukshorn CJ, Campfield LA. Effects of weekly administration of pegylated recombinant human $\mathrm{OB}$ protein on appetite profile and energy metabolism in obese men. Am J Clin Nutr. 2001; 74: 426-434.

[91] Asakawa A, Inui A, Inui T, Katsuura G, Fujino MA, Kasuga M. Leptin treatment ameliorates anxiety in ob/ob mice. J Diabetes Complications. 2003; 17: 105-107. 
[92] Drown DJ. Metformin: effective in the prevention of new-onset type 2 diabetes?Prog Cardiovasc Nurs. 2008; 23: 93-94.

[93] Atabek ME, Pirgon O. Use of metformin in obese adolescents with hyperinsulinemia: a 6-month, randomized, double-blind, placebo-controlled clinical trial. J Pediatr Endocrinol Metab. 2008; 21: 339-348.

[94] Zhang JL, Zheng X, Zou DJ, Qiu JL, Zhao XX, Qin YW. Effect of metformin on weight gain during antihypertensive treatment with a beta-blocker in Chinese patients. Am J Hypertens. 2009; Jul 2. [Epub ahead of print].

[95] Gudmundsdottir H, Aksnes H, Heldal K, Krogh A, Froyshov S, Rudberg N, Os I. Metformin and antihypertensive therapy with drugs blocking the renin angiotensin system, a cause of concern? Clin Nephrol. 2006; 66: 380-385.

[96] Khanderia U, Pop-Busui R, Eagle KA. Thiazolidinediones in type 2 diabetes: a cardiology perspective. Ann Pharmacother. 2008; 42: 1466-1474.

[97] Hsiao FY, Huang WF, Wen YW, Chen PF, Kuo KN, Tsai YW. Thiazolidinediones and cardiovascular events in patients with type 2 diabetes mellitus: A retrospective cohort study of over 473000 patients using the national health insurance database in Taiwan. Drug Saf. 2009; 32: 675-690.

[98] Gupta AK, Bray GA, Greenway FL, Martin CK, Johnson WD, Smith SR. Pioglitazone, but not metformin, reduces liver fat in Type-2 diabetes mellitus independent of weight changes. J Diabetes Complications. 2009; Jul 3 [Epub ahead of print].

[99] Chen G, McAlister FA, Walker RL, Hemmelgam BR, Campbell NR. Cardiovascular outcomes in Framingham Participants with diabetes: the importance of blood pressure. Hypertension. 2011; Mar 14. [Epub ahead of print].

[100] Klonoff DC. United Kingdom Prospective Diabetes Study follow-up studies establish a legacy effect of therapy for hyoerglycemia but not hypertension. J Diabetes Sci Thechnol. 2008: 2: 922-924.

[101] Kalaitzidis R, Bakris G. Management of hypertension in patients with diabetes: the place of angiotensin-II receptor blockers. Diabetes Obes Metab. 2009; 11: 757-769.

[102] Hansson L. The Hypertension Optimal Treatment study and the importance of lowering blood pressure. J Hypertens. Suppl. 1999; 17: S9-S13.

[103] Mancia G. Optimal control of blood pressure in patients with diabetes reduces the incidence of macro and microvascular events. J Hypertens. Suppl. 2007; 25: S7-S12.

[104] Brenner BM, Cooper ME, De Zeeuw D, Keane WF, Mitch WE, Parving HH. Effects of Losartan on renal and cardiovascular outcomes in patients with type 2 diabetes and nephropathy. N Engl J Med. 2001; 345: 861-869.

[105] Lewis EJ, Hunsicker LG, Rodby RA; Collaborative study group. A clinical trial in type 2 diabetic nephropathy. Am J Kidney. 2001; 38 ( Suppl 1): S191-S194.

[106] Zanchetti A, Ruilope LM. Antihypertensive treatment in patients with type-2 diabetes mellitus: what guidance from recent controlled randomized trials? J Hypertens. 2002; 20: 2099-2110.

[107] Gradman AH. Rationale for triple-combination therapy for management of high blood pressure. J Clin Hypertens. (Greenwich). 2010; 12: 869-878.

[108] Bakris GL, Hester A, Dahlof B, Pitt B, Velazquez E, Staikos-Byrne L, Shi V, Jamerson K. ACCOMPLISH Investigators. The diabetes subgroup baseline characteristics of the avoiding cardiovascular events through combination therapy in patients living 
with systolic hypertension (ACCOMPLISH) trials. J Cardiometab Syndr. 2008; 3: 229-233.

[109] Litthell HO. Considerations in the treatment of insulin resistance and related disorders with a new sympatholytic agents. J Hypertens. Suppl. 1997; 15: S39-S42.

[110] Kojima M, Dohi Y, Ohashi M, Sato K, Kimura G. Crucial role of kidney function in resistance to antihypertensive therapy in patients with diabetes mellitus. J Hypertens. 2010; 28: 2323-2328.

[111] Czemichow S, Zanchetti A, Tumbull F, Barzi F, Ninomiya T, Kengne AP, Lambers Heerspink HJ, Perkovic V, Huxley R, Arima H, Patel A, Chalmers J, Woodward M, MacMahon S, Neal B; Blood Pressure Lowering Treatment Trialists' Collaboration. The effects of blood pressure reduction and of different blood pressure-lowering regimens on major cardiovascular events according to baseline blood pressure: meta-analysis of randomized trials. J Hypertens. 2011; 29: 4-16.

[112] Perret-Guillaume C, Joly L, Jankowski P, Benetos A. Benefits of the RAS blockade: clinical evidence before the ONTARGET study. J Hypertens. 2009; 279Suppl 2): S53S57.

[113] Lewin AJ, Weir MR. Antihypertensive efficacy and tolerability of irbesartan/hydrochlorothiazide in hypertensive patients stratified by body mass index and type 2 diabetes mellitus status: a post hoc subgroup analysis of the irbesartan/HCTZ Blood Pressure Reduction in Diverse Patients Populations trial. Clin Ther. 2008; 30: 2354-2365.

[114] Sowers JR, Neutel JM, Saunders E, Bakris GL, Cushman WC, Ferdinand KC, Ofili EO, Weber MA: INCLUSIVE Investigators. J Clin Hypertens (Greenwich). 2006; 8: 470480 .

[115] Grassi G, Mancia G. Implementation of new evidence into hypertension guidelines: the case of the ONTARGET and TRANSCEND trials. J Hypertens. 2009; 27 (Suppl 2); S40-S44.

[116] Sleight P, Redon J, Verdecchia P, Mancia G, Gao P, Fagard R, Schumacher H, Weber M, Bohm M, Williams B, Pogue J, Koon T, Yusuf S; ONTARGET investigators. Prognostic value of blood pressure in patients with high vascular risk in the Ongoing Telmisartan Alone and in combination with Ramipril Global Endopoint Trial study. J Hypertens. 2009; 27: 1360-1369.

[117] Unger T. The ongoing telmisartan alone and in combination with ramipril global endpoint trial program. Am J Cardiol. 2003; 91: 28G-34G.

[118] Kurtz TW. Beyond the classic angiotensin-receptor-blocker profile. Nat Clin Prac Cardiovasc Med. 2008; 5 Suppl 1: S19-S26.

[119] Makita S, Abiko A, Naganuma Y, Moriai Y, Nakamura M. Effects of telmisartan on adiponectin levels and body weight in hypertensive patients with glucose intolerance. Metabolism. 2008; 57: 1473-1478.

[120] Takimoto C, Kumagai H, Osaka M, Sakata K, Onami T, Kamayachi T, Iigaya K, Hayashi K, Saruta T, Itoh H. Candesartan and insulin reduce renal sympathetic nerve activity in hypertensive type 1 diabetic rats. Hypertens Res. 2008; 31: 1941-51.

[121] Ruilpe LM, Segura J. The importance of integrated risk management when treating patients with hypertension: benefits of angiotensin II receptor antagonist therapy. Clin Exp Hypertens. 2008; 30: 397-414. 
[122] Scheen AJ. Prevention of type 2 diabetes mellitus through inhibition of the renninangiotensin system. Drugs. 2005; 64: 2537-2565.

[123] Weir MR. Effects of renin-angiotensin system inhibition on end-organ protection: can we do better? Clin Ther. 2007; 29: 1803-1824.

[124] Taylor AA, Pool JL. Clinical role of direct renin inhibition in hypertension. Am J Ther. 2011; Feb 10. [Epub ahead of print].

[125] Basile J, Babazadeh S, Lillestol M, Botha J, Yukovic C, Weitzman R. Comparison of aliskiren/hydrochlorothiazide combination therapy with hydrochlorothiazide monotherapy in older patients with stage 2 systolic hypertension: Results of the ACTION study. J Clin Hypertens. (Greenwich). 2011; 13: 162-169.

[126] Basile J, Babazadeh S, Lilestol M, Botha J, Yukovic C, Weltzman R. Comparison of aliskiren/hydrocholorothiazide combination therapy with hydrocholorothiazide monotherapy in older patients with stage 2 systolic hypertension: results of the ACTION study. J Clin Hypertens (Greenwich). 2011; 13: 162-168.

[127] Howard CG, Mullins JJ, Mitchel KD. Direct renin inhibition with aliskiren normalizes blood pressure in Cyp1a1-Ren2 transgenic rats with inducible angiotensin IIdependent malignant hypertension. Am J Med Sci. 2011; Feb 23. [Epub ahead of print].

[128] Gao D, Ning N, Niu X, Wei J, Sun P, Hao G. Aliskiren vs. angiotensin receptor blockers in hypertension: meta-analysis of randomized controlled trials. Am J Hypertens. 2011. Feb 3. [Epub ahead in print].

[129] Persson F, Lewis JB, Lewis EJ, Rossing P, Hollenberg NK, Parving HH. AVOID Study Investigators. Impact of baseline renal function on the efficacy and safety of aliskiren added to losartan in patients with type 2 diabetes and nephropathy. Diabetes Care. 2010; 33: 2304-2309.

[130] Persson F, Rossing P, Reinhard H, Juhi T, Stehouwer CD, Schalkwijk C, Danser AH, Boomsma F, Frandsen E, Parving HH. Optimal antiproteinuric dose of aliskiren in type 2 diabetes mellitus: a randomised crossover trial. Diabetologia. 2010; 53: 15761580.

[131] Pitt B. RAAS inhibition/blockade in patients with cardiovascular disease: Implications of recent large scale randomized trials for clinical practice. Heart. 2009; Apr 27. [Epub ahead of print].

[132] Kjeidsen SE, Weber M, Oparil S, Jamerson KA. Combining RAAS and calcium channel blockade: ACCOMPLISH in perspective. Blood Press. 2008; 17: 260-269.

[133] Bramlage P. Fixed-dose combinations of renin-angiotensin blocking agents with calcium channel blockers or hydrochlorothiazide in the treatment of hypertension. Expert Opin Pharmacother. 2009; 10: 1755-1767.

[134] Jemerson K, Weber MA, Bakris GL, Dahlof B, Pitt B, Shi V, Hester A, Gupte J, Gatlin M, Velazquez EJ. ACCOMPLISH Trial Investigators. (Collaborators, 554). Benazepril plus amlodipine or hydrocholorothiazide for hypertension in high-risk patients. $\mathrm{N}$ Engl J Med. 2008; 359: 2417-2428.

[135] Bakris GL, Sarafidis PA, Weir MR, Dahlof B, Pitt B, Jamerson K, Velazquez EJ, StaikosByrne L, Kelly RY, Shi V, Chiang YT, Weber MA. ACCOMPLISH Trial Investigators (Collaborators, 554). Renal outcomes with different fixed-dose combination therapies in patients with hypertension at high risk for cardiovascular 
events (ACCOMPLISH): a pre-specified secondary analysis of a randomized controlled trial. Lancet. 2010; 375: 1173-1181.

[136] Martinez-Martin FJ, Saiz-Satjes M. Add-on manidipine versus amolodipine in diabetic patients with hypertension and microalbuminuria: the MANDHA study. Exprt Rev Cardiovasc Ther. 2008; 6: 1347-1355.

[137] Weiner N, Folker A, Murphy JA, Hung E, Bard M, Perkelcald A, Sowers JR, Bakris GL. Effect of fixed-dose ACE-inhibitor.calcium channel blocker combination therapy vs. ACE-inhibitor monotherapy on arterial compliance in hypertensive patients with type 2 diabetes. Prev Cardiol. 2005; 8: 87-92.

[138] Ruilope LM. Long-term protection in at-risk hypertensive patienrs-a role for nifedipine GITS? Blood Press. 2002; 11: 106-109.

[139] Weycker D, Edelsberg J, Vinncze G, Kjeldsen SE, Jamersson K, Khan ZM, Oster G. Risk of diabetes in real-world setting among patients initiating antihypertensive therapy with valsartan or amlodipine. J Hum Hypertens. 2007; 21: 374-380.

[140] Kuti EL, Baker WL, White CM. The development of new-onset type 2 diabetes associated with choosing a calcium channel blocker compared to a diuretic or betablockers. Curr Med Res Opin. 2007; 23: 1239-1244.

[141] Rosen, P.; Ohly, P.; Gleichmann, H. Experimental benefit of moxonidine on glucose metabolism and insulin secretion in the fructose-fed rat. J. Hypertens..Suppl. 1997; 15(1): S31-S38.

[142] Sun, Z.; Emsberger, P. Marked insulin resistance in obese spontaneously hypertensive rat adipocytes is ameliorated by in vivo but not in vitro treatment with moxonidine. J. Pharmacol. Exp. Ther. 2007; 320(2): 845-852.

[143] Kaaja, R.; Kujala, S.; Manhem, K.; Katzman, P.; Kibarskis, A.; Antikainen, R.; Yliharsila, H.; Erkkola, R.; Tuomilehto, J. Effects of sympatholytic therapy on insulin sensitivity indices in hypertensive postmenopausal women. Int. J. Clin. Pharmacol. Ther. 2007; 45(7): 394-401.

[144] Sanjuliani, A.F.; de Abreu, V.G.; Francischetti, E.A. Selective imidazoline agonist moxonidine in obese hypertensive patients. Int. J. Clin. Prac. 2006; 60(5): 621-625.

[145] Pater C, Bhatnagar D, Berrou JP, Luszick J, Beckmann K. A novel approach to treatment of hypertension in diabetic patients- a multicenter, double-blind, randomized study comparing the efficacy of combination therapy of Eprosartan versus Ramipril with low-dose Hydrochlorothiazide and Moxonidine on blood pressure levels in patients with hypertension and associated diabetes mellitus type 2-rational and design [ISRCTN5525285]. Curr Controlled Trials in Cardiovas Med. 2004; 5:9. Doi:10.1186/1468-6708-5-0.

[146] Rayner B. Selective imidazoline agonist moxonidine plus the ACE inhibitor ramipril in hypertensive patients with impaired insulin sensitivity: partner in a successful MARRIAGE? Curr Med Res Opin. 2004; 20: 359-367.

[147] Velliquette, R.A.; Kossover, R.; Previs, S.F.; Ernsberger, P. Lipid-lowering actions of imidazoline antihypertensive agents in metabolic syndrome X. Naunyn Schmiedebergs Arch. Pharmacol. 2006; 372(4): 300-312.

[148] Vonend, O.; Marsalek, P.; Russ, H.; Wulkow, R.; Oberhauser, V.; Rump, L.C. Moxonidine treatment of hypertensive patients with advanced renal failure. $J$. Hypertens. 2003; 21(9): 1709-1717. 
[149] Mukaddam-Daher, S.; Menaouar, A.; El-Ayoubi, R.; Gutkowska, J.; Jankowski, M.; Velliquette, R.A.; Ernsberger, P. Cardiac effects of moxonidine in spontaneously hypertensive obese rats. Ann. N. Y. Acad. Sci. 2003; 1009: 244-250.

[150] van Zweiten, P.A. Centrally acting antihypertensive drugs. Present and future. Clin. Exp. Hypertens. 1999; 2(5-6): 859-873.

[151] Head, G.A. Central imidazoline- and alpha2-receptors involved in the cardiovascular actions of centrally acting antihypertensive agents. Ann. N. Y. Acad. Sci. 1999; 881: 279-286.

[152] Motz, W.; Strauer, B.E. Therapy of hypertensive cardiac hypertrophy and impaired coronary microcirculation. J. Cardiovasc. Pharmacol. 1994; 24 Suppl 1: S34-S38.

[153] Ziegler, D.; Haxhiu, M.A.; Kaan, E.C.; Papp, J.G.; Emsberger, P. Pharmacology of moxonidine, a I1-imidazoline receptor agonist. J. Cardiovasc. Pharmacol. 1996; 27 Suppl 3: S26-S37.

[154] Sharma, A.M.; Wagner, T.; Marsalek, P. Moxonidine in the treatment of overweight and obese patients with the metabolic syndrome: a postmarketing surveillance study. J. Hum. Hypertens. 2004; 18(9): 669-675.

[155] Haenni, A.; Lithell, H. Moxonidine improves insulin sensitivity in insulin-resistant hypertensives. J. Hypertens. Suppl. 1999; 17(3): S29-S35.

[156] Elliot WJ, Weir DR, Black HR. Cost-effectiveness of the lower treatment goal (of JNC VI) for diabetic hypertensive patients. Join National Committee on prevention, detection, evaluation, and treatment of high blood pressure. Arch Intern Med. 2000; 160: 1277-1283.

[157] Curb JD, Pressel SL, Cutler JA. Effect of diuretic-based antihypertensive treatment on cardiovascular disease risk in older patients with isolated systolic hypertension. Jama. 1996; 276: 1886-1892.

[158] Borhani NO, Mercuni M, Borhani PA. Final outcome results of the multicenter isradipine diuretics atherosclerosis study (MIDAS). A randomized controlled trial. JAMA. 1996; 276: 785-791.

[159] The ALLHAT Officers and Coordinators for the ALLHAT Collaborative Research Group. Major outcome in high risk hypertensive patients randomized to angiotensin-converting enzyme inhibitor or calcium channel blocker vs. diuretics: the antihypertensive and lipid-lowering treatment to prevent heart attack trial (ALLHAT). JAMA. 2002; 288: 2981-2997.

[160] ALLHAT Collaborative Research Group: Major cardiovascular events in hypertensive patients randomized to doxazosin vs. chlorthalidone: the anti-hypertensive and lipid-lowering treatment to prevent heart attack trial (ALLHAT). JAMA. 2002; 283: 2971-2975.

[161] Lakshman MR, Reda DJ, Materson BJ. Diuretics and beta-blockers do not have adverse effects at 1 year on plasma lipid and lipoprotein profile in men with hypertension. Department of Veterans Affairs Cooperative Study Group on Anti hypertensive Agents. Arch Intern Med. 1998; 159: 551-558.

[162] Weir MR, Moser M. Diuretics and beta-blockers: is there a risk for dyslipidemia? Am Heart J. 2000; 139: 174-183.

[163] Moser M. Lipid abnormality and diuretics. Am Fam Physician. 1989; 40: 213-220. 
[164] The Heart Outcome Prevention Evaluation Study Investigators. Effects of an angiotensin-converting enzyme inhibitor, ramipril, on cardiovascular events in high-risk patients. N Engl J Med. 2000; 342: !45-153.

[165] Neal B, McMahon S, Chapman N: for trhe Blood Pressure Lowering Treatment Trialists' Collaboration. Effect of ACE inhibitors, calciyum antagonists, and other blood pressure lowering drugs: results of prospectively designed overviews of randomized trials. Lancet. 2000; 356: 1955-1964.

[166] Gradman AH, Acevedo C. Evolving strategies for the use of combination therapy in hypertension. Curr Hypertens Rep. 2000; 4: 343-349.

[167] Dorsch MP, Gillespie BW, Erickson SR, Bleske BE, Weder AB. Chlorthalidone reduces cardiovascular effects compared with Hydrochlorothiazide. A retrowspective cohort analysis. Hypertension. 2011; 57: 689-694.

[168] Reboldi G, Gentile G, Angeli F, Verdecchia P. Choice of ACE inhibitor combinations in hypertensive patients with type 2 diabetes: update after recent clinical trials. Vasc Health Risk Manag. 2009; 5: 411-427. 


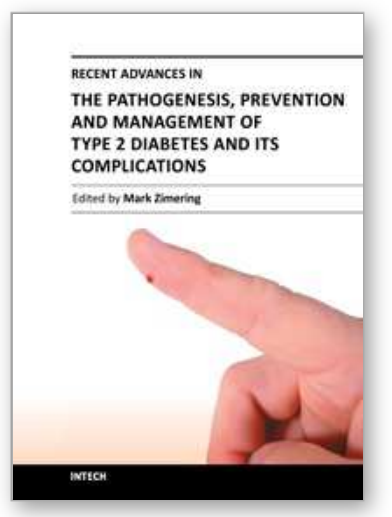

\author{
Recent Advances in the Pathogenesis, Prevention and \\ Management of Type 2 Diabetes and its Complications \\ Edited by Prof. Mark Zimering
}

ISBN 978-953-307-597-6

Hard cover, 442 pages

Publisher InTech

Published online 29, August, 2011

Published in print edition August, 2011

Type 2 diabetes â€œmellitusâ€ affects nearly 120 million persons worldwide- and according to the World Health Organization this number is expected to double by the year 2030. Owing to a rapidly increasing disease prevalence, the medical, social and economic burdens associated with the microvascular and macrovascular complications of type 2 diabetes are likely to increase dramatically in the coming decades. In this volume, leading contributors to the field review the pathogenesis, treatment and management of type 2 diabetes and its complications. They provide invaluable insight and share their discoveries about potentially important new techniques for the diagnosis, treatment and prevention of diabetic complications.

\title{
How to reference
}

In order to correctly reference this scholarly work, feel free to copy and paste the following:

Kazuko Masuo and Gavin W. Lambert (2011). Treatments for Hypertension in Type 2 Diabetes-NonPharmacological and Pharmacological Measurements, Recent Advances in the Pathogenesis, Prevention and Management of Type 2 Diabetes and its Complications, Prof. Mark Zimering (Ed.), ISBN: 978-953-307-597-6, InTech, Available from: http://www.intechopen.com/books/recent-advances-in-the-pathogenesis-preventionand-management-of-type-2-diabetes-and-its-complications/treatments-for-hypertension-in-type-2-diabetesnon-pharmacological-and-pharmacological-measurements

\section{INTECH}

open science | open minds

\author{
InTech Europe \\ University Campus STeP Ri \\ Slavka Krautzeka 83/A \\ 51000 Rijeka, Croatia \\ Phone: +385 (51) 770447 \\ Fax: $+385(51) 686166$ \\ www.intechopen.com
}

\author{
InTech China \\ Unit 405, Office Block, Hotel Equatorial Shanghai \\ No.65, Yan An Road (West), Shanghai, 200040, China \\ 中国上海市延安西路65号上海国际贵都大饭店办公楼 405 单元 \\ Phone: +86-21-62489820 \\ Fax: +86-21-62489821
}


(C) 2011 The Author(s). Licensee IntechOpen. This chapter is distributed under the terms of the Creative Commons Attribution-NonCommercialShareAlike-3.0 License, which permits use, distribution and reproduction for non-commercial purposes, provided the original is properly cited and derivative works building on this content are distributed under the same license. 